NBER WORKING PAPER SERIES

\title{
CAN A RAPIDLY-GROWING EXPORT-ORIENTED ECONOMY SMOOTHLY EXIT AN EXCHANGE RATE PEG? LESSONS FOR CHINA FROM JAPAN'S HIGH-GROWTH ERA
}

\author{
Barry Eichengreen \\ Mariko Hatase \\ Working Paper 11625 \\ http://www.nber.org/papers/w11625 \\ NATIONAL BUREAU OF ECONOMIC RESEARCH \\ 1050 Massachusetts Avenue \\ Cambridge, MA 02138 \\ September 2005
}

The views expressed here are not those of the Bank of Japan or any other organization with which the authors are affiliated. We are grateful to Miguel Fuentes and Yoichi Matsubayashi for their help with some technical aspects of the paper. For helpful comments on an earlier draft we thank Mitsuhiro Fukao, Yutaka Kosai, Akira Otani, Shigenori Shiratsuka, Miyako Suda, Wataru Takahashi, Yosuke Tsuyuguchi, participants of the seminar at the Bank of Japan and the staff of the Institute for Monetary and Economic Studies of the Bank of Japan.The views expressed herein are those of the author(s) and do not necessarily reflect the views of the National Bureau of Economic Research.

(C)2005 by Barry Eichengreen and Mariko Hatase. All rights reserved. Short sections of text, not to exceed two paragraphs, may be quoted without explicit permission provided that full credit, including $\odot$ notice, is given to the source. 
Can a Rapidly-Growing Export-Oriented Economy Smoothly Exit an Exchange Rate Peg?

Lessons for China from Japan's High-Growth Era

Barry Eichengreen and Mariko Hatase

NBER Working Paper No. 11625

September 2005

JEL No. F31, F33, N15, N65

\title{
ABSTRACT
}

We explore the parallels between Japanese currency policy after World War II and Chinese currency policy today. After two decades of pegging at 360 yen, Japan decoupled from the dollar on August 1971 and then repegged at a revalued rate of 308 yen. After stabilizing the exchange rate at this new level for about a year, greater flexibility was introduced. This phased adjustment - revaluation followed after a time by an increase in flexibility - bears more than a passing resemblance to recent Chinese policy initiatives.

We analyze the impact of Japan's exit from its peg on exports and investment. The results point to sizeable effects of the yen's revaluation on both variables, especially investment. While our analysis suggests that a rapidly-growing, export-oriented economy can operate a heavily managed float despite the presence of capital controls and the absence of sophisticated foreign currency forward markets, it underscores the importance of managing the exchange rate with domestic conditions in mind and avoiding the kind of large real appreciation that would sharply compress profits and damage investment.

For China this suggests starting with a modest band widening and a limited increase in flexibility, and not with a large step revaluation which could have a sharp negative impact on investment and growth. Our results thus provide support for the kind of measures taken at the end of July.

\author{
Barry Eichengreen \\ University of California, Berkeley \\ Department of Economics \\ 549 Evans Hall \#3880 \\ Berkeley, CA 94720-3880 \\ and NBER \\ eichengr@econ.berkeley.edu \\ Mariko Hatase \\ Institute for Monetary and Economic Studies \\ Bank Of Japan \\ PO Box 203 \\ Tokyo 100-8630 \\ JAPAN \\ mariko.hatase@boj.or.jp
}




\section{Introduction}

China's exchange rate arrangement is a continuing topic of controversy, notwithstanding the decision announced on July $21^{\text {st }}$, when the country revalued by two per cent and indicated that henceforth the rate would be allowed to depend more heavily on market conditions. Is the initial revaluation too small, or would a larger adjustment have had a devastating impact on Chinese investment and exports? Is the two per cent revaluation properly seen as part of a larger process, as a first step in the transition to greater flexibility? And, if so, is this gradual approach in which both the adjustment of the exchange rate's level and the move to greater flexibility are phased in an appropriate strategy by the Chinese authorities?

There are few historical precedents for these questions. It is hard to think of many large, export-oriented, fast-growing economies in the early stages of catch-up that exited voluntarily from a peg. One analogy is Japan in the 1970s. After two decades of pegging at 360 yen to the dollar, Japan decoupled from the dollar on August $28^{\text {th }}, 1971$, repegging on December $18^{\text {th }}$ at 308 yen in conjunction with the Smithsonian Agreement. The new peg lasted 14 months, after which greater flexibility was introduced.

In this paper we use this historical precedent to shed light on current Chinese prospects. We argue that there are extensive parallels between the two cases, extending even to the gradual nature of the adjustment - a one-time step revaluation followed after a period by the shift to freer floating. At the same time, the analogy must be developed carefully. Japan then was more advanced than China now. Its per capita incomes were higher, and technological sophistication was greater relative to the United States. While government involvement in the economy was extensive, such involvement was not as 
pervasive as in China. Japan also had more sophisticated financial markets and a betterdeveloped monetary transmission mechanism. Moreover, its initial devaluation was larger. Still, and notwithstanding these differences, Japan's experience from the 1950s through the 1970s can provide useful insight into China's current options.

Our analysis of the country's experience from the 1950s through the 1970s suggests that a rapidly-growing, export-oriented industrializing economy can exit a currency peg without significantly disrupting its growth, its export growth in particular. It can operate a more flexible exchange rate despite the maintenance of capital controls and not having well-developed foreign currency forward markets. But it is important for the country to manage its exchange rate with domestic economic conditions in mind and to avoid the kind of large real appreciation that could have a sharply negative impact on profitability and investment. For China, this suggests starting with a modest revaluation and a progressive widening of the band - the policies actually adopted - is preferable to the kind of large revaluation sometimes advocated by foreign observers. ${ }^{1}$

\section{Background to the Study}

Japan in the 1950s and 1960s, like China in the 1980s and 1990s, grew at rates well in excess of those witnessed anytime in its previous history. ${ }^{2}$ GNP growth in Japan between 1955 and 1971 averaged 9.3 per cent per annum. This was a dramatic acceleration from 1913-1950, when growth had averaged 2.0 per cent, and from 1885-

\footnotetext{
${ }^{1}$ See inter alia Goldstein and Lardy (2003).

${ }^{2}$ The detail provided here may be more than is required by some Japanese readers already familiar with the structure of the economy. However, it may be important to provide this information for readers interested in the comparison with China, especially when it comes to topics like the organization of the foreign exchange market, the monetary transmission mechanism, and the operation of capital controls.
} 
1913, when it had proceeded at 2.6 per cent. ${ }^{3}$ China's economy has expanded at nearly 10 per cent per annum since economic reform commenced in 1978, which is similarly a revolution in growth performance. (See Table 1.)

In Japan after World War II as in China today, growth was fueled by exports, facilitated by the transfer of advanced technology, sustained by investment, and supported by elastic supplies of cheap labor. Japan's exports grew at an annual average rate of 16.9 per cent between 1955 and 1971, more than half again as fast as output. ${ }^{4}$ Exports quadrupled in volume between 1959 and 1969 and increased by a further onethird in the next two years, impressive performance even by modern Chinese standards. The other side of this coin was a doubling of Japan's share of the imports of the rest of the world in the course of the 1960s and especially rapid growth in the share of U.S. merchandise imports accounted for by Japanese suppliers. (See Table 2.) Japan's surplus with the U.S. was more than $\$ 1$ billion in 1970, reflecting the buoyant U.S. market for the country's exports of consumer goods in conjunction with Japan's need to finance imports of energy and raw materials from other suppliers. Strong surpluses allowed Japan to more than double its foreign reserves between 1967 and $1970 .^{5}$

By the end of the 1960s, Japanese gross national savings rates had risen to 40 per cent and the investment/GNP ratio had reached 35 per cent, levels broadly comparable to those in China today. ${ }^{6}$ (See Table 3.) Employment in agriculture declined by 3 per cent

\footnotetext{
${ }^{3}$ The 1913-1950 figure is depressed by the exceptional events of the post-World War II period. Over the shorter period 1913-1940, growth averaged 4.0 per cent.

${ }^{4}$ This nearly matches rates of export growth in China, which have been running on the order of 20 per cent per annum in recent years.

5 Though outstanding reserves had been constant during the high growth era, they started increasing in 1968. Reserves of the end of 1970 were \$4.4 billion, up from \$2.0 billion at the end of 1967.

${ }^{6}$ The former showed about 50 per cent increase, while the latter achieved almost 90 per cent increase compared with two decades earlier. Between 1956 and 1973 real fixed nonresidential capital investment grew at an annual average rate of 16 per cent.
} 
per annum both in the second half of the 1950s and first half of the 1960s and was offset

by the rapid growth of employment in the modern sector, led by manufacturing, facilitating industries, construction, and to a lesser extent services. ${ }^{7}$ According to Ohkawa and Rosovsky (1973), more than 70 per cent of Japan's full-time farm households were in a condition of underemployment after World War II. Elastic supplies of labor could thus be made available to industry without driving down agricultural output. ${ }^{8}$ Contemporaries referred to a dual wage structure in which the wages of employees of enterprises in the modern sector were at least twice the levels of those in the agricultural sector - indicative of a strong incentive for labor reallocation. ${ }^{9}$ In all these respects, the parallels with contemporary China are clear.

But there are also important differences. Japan at the beginning of its highgrowth period was a relatively advanced industrial economy, reflecting the development of a modern textile industry in the $19^{\text {th }}$ century and then steel and shipbuilding in the first half of the $20^{\text {th }} \cdot{ }^{10}$ China, in contrast, had a dearth of modern industry when embarking on

\footnotetext{
${ }^{7}$ Ohkawa and Rosovsky (1973), Table 5.2.

${ }^{8}$ Ohkawa and Rosovsky (1973), p.133. That widespread underemployment was more than a transitory post-World War II phenomenon is evident in the rationale for the famous National Income Doubling Plan of 1960, which was precisely to reduce the extent of disguised unemployment. Prime Minister Hayato Ikeda announced the Income Doubling Plan immediately after he took office in 1960. The plan was crystallized as a cabinet decision in December 1960 (Yasuba and Inoki 1989, p.18). Its primary goals were a sharp improvement in living standards and the achievement of full employment. The plan intended to achieve an annual averaged growth of 7.2 per cent between fiscal year of 1961 and 1966 . To reach that target, the following areas were given priority; improvement of social infrastructure and industrial structure, enhancement of trade and international economic cooperation, and stimulating technology and human resources (Kosai 1989, pp.210-2).

${ }^{9}$ More precisely, Ohkawa and Rosovsky (1973) suggest that wages in large industrial enterprises were as much as twice wages in small and medium-size firms, while wages in the modern sector broadly defined (small and large firms alike) were twice the levels prevailing in agriculture.

${ }^{10}$ Nakamura (1993) categorizes Japanese cotton spinning as "modern industry" from the late $1880 \mathrm{~s}$ (Nakamura 1993, p.84). Takamura (1971) concludes that the modern cotton spinning industry was established by the late 1890s (Takamura 1971, p.209). Okazaki (1993, p.227) argues that the Japanese steel industry was able to stand on its own feet, with the help of limited protection from import competition, from the late 1920s. The shipbuilding industry reached international standards by the early $20^{\text {th }}$ century (Ishii 1991, p.228). Shipbuilding recovered relatively quickly after World War II; by 1955 more than 85 per cent of its products were exported (Mitsubishi Heavy Industry, Ltd. 1967, pp.7, 22, 49-51). We exclude
} 
reform in 1978. Japanese per capita GDP in 1950 expressed in 1990 international GearyKhamis dollars was $\$ 1,926$, whereas Chinese per capita GDP in 1978 was $\$ 979$. Five years later the comparable figures were $\$ 2,772$ and $\$ 1,265 .^{11}$

The Japanese system of technology transfer was also different. Whereas China today relies on foreign direct investment for technology transfer, Japan relied on licensing and reverse engineering. The Japanese government limited inward FDI for three decades after 1950. Mason (1982) and others argue that restrictions on market access for foreign multinationals facilitated the country's efforts to license foreign technologies. ${ }^{12}$ They conclude that the relatively advanced state of the Japanese economy, together with the lower tacit component of advanced technology compared to today, enhanced the effectiveness of this approach to technology transfer.

The structure of labor markets was different as well. In Japan in the 1950s, labor was free to move from the countryside to the cities; the freedom to select one's occupation and place of residence were individual liberties guaranteed since the early Meiji period, the late 19 th century. ${ }^{13}$ In China, in contrast, the authorities attempt to regulate the movement of the rural population to the cities in order to avoid threats to the

motor vehicles and electrical machinery from this list of industries that developed significantly before World War II; although Toyota produced trucks for military use in the 1940s, the production of passenger cars only started after the war. The Ministry of Trade and Industry imposed significant restrictions on imports in order to protect the passenger car industry in the 1950s (Toyota Motor Corporation 1987, pp.834, 259-60). Although there was prewar production of lighting equipment, radios and electric wires, the leading companies producing electrical equipment and electronics, such as Sony and Sanyo Electric, were only established after World War II.

${ }_{11}^{11}$ According to estimates in Maddison (2001), Table C3-c.

${ }_{12}$ Kosai (1989) points out that one of the reasons for restricting inward FDI was the fear that this would hamper domestic research and development.

${ }^{13}$ In the very early stage of Meiji period, a series of reforms which enabled people to select one's occupation and to move freely conducted; the class system separating warriors, farmers, craftsmen and merchants abolished in 1869 and the trades of agricultural field were allowed in 1872. For details, see Nakamura (1993), pp.62-63. 
public order, using a system of official work permits or visa. ${ }^{14}$ The effectiveness of these measures is difficult to evaluate, since illegal internal migration is rife. So too are the implications for the China-Japan comparison. On the one hand, China today has even larger reserves of underemployed rural labor anxious to find work in the high-wage modern sector. On the other hand, that labor's freedom to move is significantly less. ${ }^{15}$

In addition, the banking and financial system was stronger in Japan. Banks were not burdened by the overhang of nonperforming loans plaguing the Big Four banks in China. Their lending decisions were guided by commercial motives, although subject to window guidance (quantitative limits on the growth of lending by individual banks, described in more detail below). The lending charges of Japanese banks could be adjusted freely (even if published lending rates were relatively stable, the banks still adjusted the compulsory depositions required of their customers). ${ }^{16}$ In China, banks have

\footnotetext{
${ }^{14}$ In addition, already in the 1950s employment in large Japanese manufacturing firms was characterized by long tenures and low involuntary separation rates. See Abegglen (1958) and Odaka (1999). Labor relations in the high growth era were well known for enterprise unionism. The unions of major firms played important roles in determining wages through negotiations with management. The emphasis of these unions on job security over wage growth is often cited as one of the reasons for low levels of wage rigidity in Japan compared to other developed countries. Shimada, Hosokawa and Seike (1982) point out that rates of wage increase were sensitive to factors affecting corporate profits in Japan while U.S. wages were less flexible. Odaka (1999) points out that the co-operative attitudes of unions worked as protection against cost inflation. For example, unions took "an extremely co-operative stance towards firms' policies of streamlining and wage restraint" after the first oil shock (p.146). China today does not possess equally well-organized union movement or comparably stable employment relations.

${ }^{15}$ To put it another way, one rationale for maintaining an undervalued exchange rate is to offset another distortion (rural underemployment) that makes the social returns to employment in the modern exportoriented sector much higher than the returns to employment in the rural sector. See Dooley, FolkertsLandau and Garber (2003). Since China today has more rural underemployment, it can be argued that it should avoid further revaluation. On the other hand, this argument for sticking to an undervalued rate in order to accelerate the movement of rural labor to the modern sector makes no sense when the authorities are at the same time attempting to limit internal migration for fear of social dislocations.

${ }^{16}$ For the details of lending rate adjustments using compulsory deposits, see Ministry of Finance (1991a, pp.267-273).
} 
less freedom to adjust lending rates, and in any case such rates matter less for lenders and borrowers with soft budget constraints. ${ }^{17}$

Monetary control exhibited similarities as well as differences. In the 1950s the

BOJ used the discount rate, discount-rate surcharges for excess borrowing, and window guidance to influence the growth of money and credit. ${ }^{18}$ It used changes in required reserves, which altered the banks' capacity to lend, starting in $1959 .{ }^{19}$ From the mid1950s it also sold short term government securities. It purchased and sold long term bonds, especially after the government resumed issuing these in 1966. It purchased private bills (prime bills or promissory notes issued by banks with prime bills attached as collateral, which were introduced in 1972).

At the same time, open market operations of the normal sort did not really exist, since there was little in the way of a liquid bond market. ${ }^{20}$ The central bank rationed its

\footnotetext{
${ }^{17}$ Although it can be argued that the bribes paid to loan officers in order to obtain bank credit serves a similar function to compulsory deposits.

${ }^{18}$ Discount rates applied to BOJ lending to private banks (discounts and loans on bills). From 1946 to 1963 , the BOJ applied discount rates to pre-determined amounts of BOJ lending and amounts over the ceiling were subject to higher interest rates. By changing the level of the ceiling, the BOJ could affect the lending behavior of banks.

${ }^{19}$ According to Suzuki (1987, pp.322-3), "The reserve deposit requirement system is a system under which commercial financial institutions are required to deposit in non-interest bearing accounts at the Bank of Japan amounts in certain proportions to their deposits and other liabilities (these proportions are called 'reserve ratios'). ... During periods of financial tightening, and subsequent loosening or relaxation until around 1980, reserve requirements were changed relatively frequently and thus were a powerful policy instrument for the adjustment of the liquidity position of financial institutions, together with lending policy and securities and bills operations."

${ }^{20}$ A study that emphasizes these features of Japanese financial markets and monetary policy is Tachi and Komiya (1960, p.288). They write:

"One of the peculiar features of the Japanese monetary system and monetary policy in recent years as compared with those of other advanced countries is the prevalence of direct control measures such as credit rationing at the discount window of the Bank of Japan, the fixing of almost all rates of interest by, or under the direction of, the monetary authorities, or the regulation of new issues of bonds virtually on a quota system. In Japan, because of the absence of an open market in such short-term securities as Treasury bills and acceptance, the Bank of Japan depends on loans as the principal means of extending central bank credit to the banking system."
}

Another example of this view of the financial system can be found in Bank of Japan (1976). There one finds the passage (pp.123-125, authors' translation):

"There are three kinds of conventional tools for monetary policy: control of discount rate, open market operations, and control of required reserve ratios. Among these three, control of the 
discounts and loans against bills. It imposed window guidance on the large city banks in the 1950s and then on the long-term credit banks, large regional banks and trust banks in the 1960s. It also used informal tools for controlling corporate bond issuance. ${ }^{21}$ When selling long term government bonds in the late 1960s, the BOJ informally allocated them to banks in specific amounts. ${ }^{22}$ This reliance on moral suasion resembles current practice in China, where the authorities similarly attempt to influence bank lending and thereby money and credit conditions by instructing the banks to limit and adjust their lending to accommodate the objectives of monetary policy. ${ }^{23}$

discount rate has been used as the most important policy tool...Open market operations cannot be conducted with flexibility due to underdevelopment of bond market. The major method of monetary control was BOJ lending with discount rate control. So called window guidance was used as a supplementary tool. ... The conventional tools make it possible to control private banks' activities through the effect of interest rate and liquidity on their cash position. However, it has not been easy to obtain immediate effects of such policies, especially for tightening occasions, as the function of interest rate and market has not been sufficient. Therefore, the BOJ used window guidance as a supplementary tool for conventional methods."

In his assessment of monetary policy from the late 1960s through the early 1970s, Kosai (1989, p.228) concludes that "there was a sign that monetary policy tools transformed from BOJ lending, call rate and window guidance into open market operations and interest rates."

${ }^{21}$ From 1949 to 1956, the BOJ influenced corporate bond issuance by determining the eligibility of bonds for use as collateral. Financial intermediaries, mainly banks, purchased about 90 per cent of corporate bonds, and those bonds were immediately passed to the BOJ as collateral for BOJ lending. When monetary conditions eased in the mid 1950s, the banks' dependence on BOJ lending declined and the BOJ's de facto power through this mechanism disappeared. After the pre-issue examination of eligibility was eliminated, eight major banks, including Industrial Bank of Japan and the major city banks, developed informal arrangements whereby they determined detailed conditions for corporate bond issuance in conjunction with the BOJ. Thus, the central bank continued to exercise considerable influence over the volume of issuance (Ministry of Finance 1991b, pp.570-2, Association of Public and Corporate Bond Underwriters 1980, pp.232-3, 239).

${ }^{22}$ When the BOJ broadened the practice of purchasing bonds in 1962, it allocated those transactions 75 per cent to city banks, 18 per cent to regional banks, and 3.5 per cent to trust banks and long-term credit banks. Within those categories it assigned amounts to each institution according to the size of its balance sheet (Ministry of Finance, 1991a, pp.189-190). When the BOJ began purchasing long-term government bonds in 1967, a formal ceiling on the size of the operation was not set. But the BOJ set informal guidelines that worked as a de facto ceiling. According to Ministry of Finance (1991a, p.310, authors' translation), the BOJ considered that "about 70 per cent of the outstanding [government bonds] held by financial institutions, excluding Norin Chukin Bank and securities companies, are the appropriate ceiling for the operation." Following this guideline, each entity taking part in such operations was allocated an amount equal to 70 per cent of its holdings of eligible bonds.

${ }^{23}$ Typically, the People's Bank of China convenes a meeting to explain its monetary policy intentions and uses moral suasion to guide the commercial banks to adjust their lending policies accordingly. For example, "in the first quarter of 2004, considering overinvestment in some regions and industries, the PBC held monthly meetings to review economic and financial development and strengthened warnings for the 
To be sure, the extent of this reliance differed across markets and over time. As

for short-term money markets, the call market tended to be subject to controls though the degree of restrictions changed over time. "The experts including the authorities

considered that the level of call rates were abnormally high" in the early stage of the high growth era and, thus, moral suasions by the BOJ or self-imposed restrictions by financial institutions for call rates were believed to be necessary. ${ }^{24}$ However, the coverage of these restrictions was limited and there were loopholes allowing effective rates to fluctuate to some extent. Thus, "call loan rates worked as indicators for the condition of financial market as a whole though the function was imperfect." ${ }^{25}$ As for bond markets, yields of government-guaranteed bonds, bank debentures and corporate bonds in secondary markets could fluctuate relatively freely, while those in primary markets were kept in artificially low levels. By contrast, yields of JGBs in both primary and secondary markets were strictly controlled. ${ }^{26}$ But despite these variations, and notwithstanding the

commercial banks to guard against potential risks. Commercial banks are urged to maintain sound operations and sustained business development with intensified capital constraints and reasonable loan growth." In addition to monthly meetings, it announced a notice on 18 January, requiring commercial banks to take positive measures to control loans to such overheated industries as steel, aluminum and cement. Furthermore, it "summoned all commercial banks to carry out a specific analysis on current economic and financial situations, requiring a mechanism to be introduced to control loan expansion in line with their own risk-control capacities and capital adequacy status." (People's Bank of China, 2004a, p.51.) That said, there has been movement in the conduct of these policy in recent years, with the People's Bank beginning to make growing use of interest rates to shape the growth of bank credit.

24 Ministry of Finance (1991a), p. 87. From 1948 to 1957, the BOJ "guided" the market participants to trade at a particular overnight interest rate in the call market. This de facto regulation on call loan interest rates was abolished in 1957 but then self-imposed controls by financial institutions started two years later. The effectiveness of the self-imposed controls was not satisfactory and the actual interest rates applied to transactions were higher than published rates. Thus, the BOJ again started to "guide" call loan brokers in 1962 and in the mid-1960s this control gradually moved towards quotation system under which call loan brokers decided quoted prices with the consultation to the BOJ (Ministry of Finance 1991a, pp.89, 111, 155-6, 157-8).

25 Ministry of Finance (1991a), p.313.

26 Ministry of Finance (1991a), pp.313-4, Kure and Shima (1987), pp.56-7. In the case of the JGB, the amount of circulation in the secondary market was limited as most part of the JGBs were held by financial institutions and it was said that the MOF restricted the sales of them. The MOF "guided" the securities companies to buy JGBs from individuals with prices close to those in primary markets (Bank of Japan 1986, p.529, Kure and Shima 1987, pp.56-7). 
fact that Japan had a sounder banking and financial system after World War II than China today, the mechanisms of monetary control were not entirely dissimilar.

Finally, compared to China today, government involvement in the economy was less. To be sure, volumes have been written about the industrial policies of the Ministry of Trade and Industry and the credit-allocation policies of the Ministry of Finance. The Japanese government sought to channel resources into industrial development, establishing the Reconstruction Finance Bank (eventually taken over by the Japan Development Bank) and the Export Bank of Japan (renamed the Export-Import Bank of Japan). These public financial institutions influenced Japanese development through the Fiscal Investment and Loan Programme, or FILP. ${ }^{27}$ The FILP was overseen by the Ministry of Finance, which collected public deposits at the Postal Savings system (and the resources of the public pension system) and passed them through to the JDB, the ExIm Bank, and other public financial institutions such as the Housing Loan Corporation. $^{28}$

The commercial banks, in contrast, retained basic autonomy over their loans and investments within ceilings set by window guidance. ${ }^{29}$ Although they were subject to window guidance, there was no counterpart in 1950s and 1960s Japan of the nonperforming loan problem in contemporary China, where estimates of the extent of

\footnotetext{
27 For a more detailed description of the FILP, see Suzuki (1987), pp.273-276.

${ }^{28}$ According to Suzuki (1987), the share of public banks, including the JDB and ExIm Bank, in the FILP fluctuated between 8 and 20 per cent from 1965 to 1980. Public finance corporations, such as Housing Loan Corporation usually accounted for the largest share. Outstanding of the FILP funds were 16.2 billion yen in the end of FY 1965, while all outstanding bank assets were 36.5 billion yen. While public financial institutions such as the JDB and ExIm Bank had assets comparable in size to those of Japan's largest private banks, there were in a goodly number of private banks; postal saving deposits comprised no more than 20 per cent of personal savings. Roughly speaking, then, some four-fifths of financial intermediation in Japan was based on commercial motives.

${ }^{29}$ There is some controversy over this. Authors like Mikuni and Murphy (2002) suggest that the banks came under strong moral suasion to plow their loans into capital formation in export industries in particular.
} 
nonperforming loans are on the order of 40-50 per cent of GDP. This suggests that the extension of credit for non-economic reasons was less than in China today. While it is hard to put precise figures on the share of policy loans in the portfolios of Chinese state banks, it is fair to say that the banking system, which is heavily dominated by state banks, has devoted significantly more of its resources to development lending, not always with positive results for their own balance sheets and for the development of the Chinese economy.

\section{Currency Policy}

For nearly a quarter of a century after World War II Japanese currency policy was predicated on an exchange rate pegged to the dollar and stringent capital controls. The yen was pegged at 360 on April 25, 1949 in conjunction with the Dodge Line. ${ }^{30}$ It remained there until the collapse of the Bretton Woods System in 1971.

Exchange rate stability has been portrayed as integral to the Japanese economy's rapid growth and to the rapid growth of its exports in particular. ${ }^{31}$ To be sure, in strong upswings, the demand for imports grew more rapidly than the supply of exports, and export supply was partially crowded out by domestic absorption. It was not possible to finance the resulting current account moved out of foreign reserves, since the government followed a strategy of limiting reserve accumulation in order to plow all available resources into fixed investment. This meant that the Bank of Japan had to tighten in

Others like Horiuchi (1984) are more skeptical that the authorities were in fact able to influence the allocation of bank lending in this way.

${ }^{30}$ The Dodge Line was the set of economic reforms advanced by Joseph M. Dodge in the late 1940s. Dodge was the President of Detroit Bank and appointed as an advisor to the General Headquarters of the occupying forces (GHQ). For details of the Dodge Line, see Nakamura (2003) and Miwa (2003). 
order to restrain the growth of demand, limit the deterioration of the external accounts, and defend the currency peg. This constraint on the rate of growth was referred to as the "balance of payments ceiling." 32 Fortunately, this constraint only bound at high rates of growth, at least after the beginning of the postwar period.

This observation has led observers to ask whether the yen was significantly undervalued. The consensus appears to be that the currency was overvalued at the beginning of the postwar period but that this gave way to undervaluation in the course of the high-growth years. ${ }^{33}$ Before the currency was pegged in April 1949, there had been debate over its appropriate level between Japanese officials and the Economic and Scientific Section of the Supreme Commander for the Allied Powers (SCAP). SCAP proposed a rate of 330 to the dollar, but Japanese officials preferred a lower rate in part because they anticipated that sterling and other currencies might soon be devalued against the dollar. ${ }^{34}$ The Bank of Japan (1985, p.258) observes that, at the eventual rate of 360 to the dollar, "the exchange rate was considerably overvalued given the effective price level considering black market prices. It was a challenge to adapt the Japanese economy to the newly set exchange rate.",35

Initially, tight foreign exchange controls were needed to support the currency. As Komiya (1988) puts it, "the exchange rate of 360 yen per dollar set in 1949 was significantly overvalued compared with the equilibrium rate at which the external accounts are balanced without restrictions on imports and without export enhancement

\footnotetext{
${ }^{31}$ Odaka (1989, pp.175-6, authors' translation) writes in a representative passage that "it should not be neglected that the fixed exchange rate of 360 yen against dollar was firmly kept until 1972 and that this was behind the export expansion."

${ }^{32}$ For references see Nakamura (1993), p.137 et seq. An analysis of this phenomenon is Ackley and Ishi (1976).

${ }^{33}$ Note the similarity to recent discussions of China.

${ }^{34}$ Ministry of Finance (1976), pp.430-1; Bank of Japan (1985), pp.255-6.
} 
policies."36 37 Kosai (1989) agrees with the proviso that overvaluation emerged only after sterling was devalued and inflation accelerated with the outbreak of the Korean War. ${ }^{38}$ These observations suggest at least some qualification of the conventional wisdom that an undervalued exchange rate was central to Japan's postwar growth from the start.

But with the recovery of the economy following the imposition of the Dodge Line and the rapid growth of productivity in the traded goods sector in particular, what had once been seen an overvaluation became increasingly undervaluation. ${ }^{39}$ Government-led rationalization of the metals, machinery and chemicals sectors led to reductions in production costs in industries in which Japan already had some presence in export markets. In addition, at the end of the 1950s and increasingly in the 1960s, Japan's export competitiveness was enhanced by technological progress and structural change leading to the emergence of new export products that had not been produced before in significant quantities or even at all, plastics, business machines and automobiles for example. ${ }^{40}$

Already at the end of the 1950s Shinohara (1959) used comparisons with the 1930s to argue in favor of undervaluation. ${ }^{41}$ While there is some debate over precisely when this undervaluation emerged, by the late 1960s there was a considerable amount of evidence in favor of the hypothesis. ${ }^{42}$ By this time Japan had learned how to produce many of the capital goods needed for its industrial expansion rather than importing them

\footnotetext{
35 Authors' translation.

${ }^{36}$ Komiya (1988), p.160 (authors' translation).

${ }^{37}$ Some previous studies, such as Shinohara (1959) and Fujino(1988) discuss the evaluation of the yen from the viewpoint of purchasing power parity.

${ }^{38}$ Kosai (1989), p.265.

${ }^{39}$ See inter alia Fujino (1988) and Kosai (1989).

${ }^{40}$ On this see Kojima (1972).

${ }^{41}$ Shinohara (1959), p.24.

${ }^{42}$ For questions about the timing of this shift, see for example Fujino (1988).
} 
from abroad. After 1965 the current account moved into surplus, and then from 1968 foreign reserves rose strongly. ${ }^{43}$ The balance of payments ceiling of which observers had warned no longer seemed to constrain growth even in strong expansions. ${ }^{44}$

To analyze these questions further, we have constructed nominal and real effective exchange rates for the 1950s and 1960s ${ }^{45}$ Our series are trade-weighted averages of bilateral nominal rates for 17 leading trading partners accounting for 40 to 50 per cent of total Japanese exports. ${ }^{46}$ Figure 1 for the nominal exchange rate shows that focusing exclusively on the yen-dollar exchange rate, as is typically done in discussions of the post-World War II years, understates currency variability. It also shows a tendency for the nominal effective rate to appreciate over the high-growth period as a result of devaluations against the dollar and thus the yen by other countries. ${ }^{47}$

Figure 2 plots the real effective exchange rate, constructed as wholesale prices in Japan relative to wholesale prices in other countries converted into yen. We see there how the real rate rose around the time of the Korean War, consistent with the emphasis of Kosai (1989). It then fell by 2.8 per cent from the mid-1950s through the late 1960s, although the bilateral real rate against the U.S. dollar fell by about twice this amount. ${ }^{48}$ This is consistent with the hypothesis of emerging undervaluation, although the change in the real effective rate is small. Note also that while the real bilateral rate against the

\footnotetext{
${ }^{43}$ As noted in Section 2 above.

${ }^{44}$ Ackley and Ishi (1976, p.187) note that the 1963-64 and 1966-70 cyclical expansions were the first ones that were not marked by sharp and steady declines in net exports that ultimately resulted in their moving into negative territory. As Nakamura (1993, p.167) explains this, "the current account of the balance of payments stopped being a constraint on economic growth under the exchange rate of 360 yen per dollar because international competitiveness had improved enough" (authors' translation).

${ }^{45}$ See the appendix for details on the construction of these series.

${ }^{46}$ Depending on the year in question. For purposes of the chain-weighted index, we updated the trade weights every five years.

${ }^{47}$ Such as Greece and Thailand in 1953, Iran in 1957, the Philippines in 1962 and India in 1966.
} 
United States continued to depreciate in the second half of the 1960s, the real effective rate did not. Figure 2 thus suggests that back-of-the-envelope calculations based on conveniently available U.S. and Japanese inflation rates, together with the constant bilateral exchange rate, tend to exaggerate these trends.

It can be argued that relative wholesale price indices adjusted for exchange rate changes understate the change in competitiveness, since wholesale prices are dominated by homogenous goods whose cost tends to be driven to equality by arbitrage. A better comparison for Japan would be the unit prices of exports relative to other industrial countries, since most Japanese exports were differentiated manufactures and the developed countries were Japan's main competitors in markets for these products. Figure 3 confirms that export prices rose less rapidly than wholesale prices over the high growth period, especially in the early 1950 s.

Figure 4 shows the unit value of exports since 1951 relative to the advanced economies. ${ }^{49}$ It indicates a substantial one-time improvement in Japan's international competitiveness in the first half of the 1950s, as emphasized by Shinohara (1959). There is then a further improvement as the high-growth period proceeds. Japanese export prices fell by 7 per cent between 1960 and 1962, led by declines at twice this rate in metals, machinery and chemicals, three industries that had been the target of government-led

\footnotetext{
${ }^{48}$ Again, the difference is explicable by the tendency for other countries to devalue against the dollar and therefore the yen, which lowered foreign prices when converted into yen.

${ }^{49}$ The figures here are abstracted from "Comparative Statistics" compiled by the Bank of Japan, following the classification in the Monthly Bulletin of Statistics of the United Nations. The UN's "Economic Class I" includes the U.S., Canada, Belgium, Luxembourg, France, West Germany, Italy, the Netherlands, Austria, Denmark, Norway, Portugal, Sweden, Switzerland, the U.K., Finland, Iceland, Ireland, Greece, Spain, Turkey, Yugoslavia, Japan, Australia, New Zealand and South Africa. The figures for each country reflect changes in export prices on each national currency basis. The data series for "developed countries" is aggregated after adjusting each country's export price index for nominal exchange rates fluctuations against the dollar.
} 
rationalization and modernization investment. ${ }^{50}$ After that, the unit value of Japanese exports held steady or rose slightly in periods when raw material prices were rising, but competitiveness continued to improve as a result of inflationary developments abroad and relatively rapid Japanese productivity growth and technical change. Overall, Japanese export prices fell by 29 per cent relative to those of its industrial-country competitors between 1951 and 1967. All this suggests growing undervaluation.

\section{Exiting the Peg}

Whether overvalued or undervalued, the government took the peg at 360 yen to the dollar as an "immutable condition." May 1971 the issue of yen realignment received little attention; it was the subject of little systematic planning. ${ }^{52}$ Even then, Finance Minister Mizuta continued to insist that "the best policy choice is to achieve economic stabilization under the fixed exchange rate regime." 53 Those few economists and officials who did consider the possibility of revaluation tended to dismiss it as damaging to exports, investment and confidence. ${ }^{54}$

\footnotetext{
${ }^{50}$ Krause and Sekiguchi (1976), p.420.

${ }^{51}$ Kosai (1989), p.287 (authors' translation). Thus, when German Economy Minister Ludwig Erhard visited Japan in 1958 and argued that the government should allow the currency to appreciate as part of a strategy of reducing government intervention in the economy, his remarks elicited a very strong negative reaction. The day following Erhard's remark on the evaluation of the yen, Finance Minister Eisaku Sato commented at the press conference, "though Economy Minister Erhard said that one of the causes for extremely cheap prices of Japanese goods is the level of exchange rate, the current exchange rate of 360 yen per dollar is not undervalued. If Japan would revalue its exchange rate, Japanese trade industries could not cope with it." (Nikkei Newspaper, 29 October 1958, authors' translation). In the press, Erhard's comments were interpreted as implying that a) Japan should abolish its capital controls, b) the country's wage level is too low and should be raised, c) the exchange rate of 360 yen per dollar is undervalued and it should be revalued and d) Japan should expand domestic demand (see for example Hoshino 1958).

${ }^{52}$ Bank of Japan (1986), p.303. Angel (1991, p.272) puts it more strongly, writing that "Expressions of doubt were banned absolutely within the MOF, and serious efforts were even made to prevent public discussion of the issue within the business community."

${ }^{53}$ Cited in Ministry of Finance (1992), p.374 (authors' translation).

${ }^{54}$ The prominent exceptions were the members of the Forum for Foreign Exchange Rate Policy, who recommended revaluation and shifting to a crawling peg in their report issued on 10 July 1971. However,
} 
Fears that changing the exchange rate would have negative implications for employment growth and security in the manufacturing sector led some observers to warn that tampering with the exchange rate could even provoke political unrest. ${ }^{55}$

Of course, those advocating maintenance of the dollar peg had to offer alternatives for countering the chronic current account surplus, which caused tension with foreigners, and how to handle the inflationary pressures associated with capital inflows. ${ }^{56}$ The dominant recommendation was to relax exchange controls and trade barriers in order to encourage imports. For example, Takahashi (1971) stressed the need for import liberalization. The government in fact pursued this option by selectively removing foreign exchange controls and import quotas and relaxing regulations limiting outward FDI. ${ }^{57}$ Others like Shimomura (1971) plumped instead for fiscal stimulus to encourage imports and rebalance the current account. Still others worried that this option would only intensify inflationary pressure. ${ }^{58}$

Symptomatic of the deeply ingrained nature of inherited policy, Japan continued to peg the yen to the dollar, intervening in the foreign exchange market, for two weeks after President Nixon closed the gold window. ${ }^{59}$ Foreign reserves rose by nearly 50 per

the members of the forum recommended limiting the yen's appreciation to 2 to 4 per cent a year, reflecting widespread worries about the negative repercussions of a large step revaluation.

${ }^{55}$ Bank of Japan (1986), p.305. See also Takahashi (1971) and Hayami (1982).

${ }^{56}$ The rise of trade tension with, inter alia, the United States, is of course another suggestive parallel between Japan in the 1970s and China today.

${ }^{57}$ In June 1971. The relaxation of regulations included the liberalization of outward FDI in principle. The enhancement of liberalization of inward FDI was also in the list reflecting the criticism from abroad on the slow pace of liberalization (Ministry of Finance 1992, pp.368-370).

${ }_{58}^{58}$ See for example Forum for Foreign Exchange Rate Policy (1971).

${ }^{59}$ Note that this observation is consistent with the premise of this paper that Japan can be thought of as choosing to exit from the peg rather than being forced off it by events in the United States. Another not incompatible explanation for why the monetary authorities continued to place a ceiling on the dollar exchange rate for some weeks is wanted to allow banks to hedge their open positions. Japanese banks had accumulated dollar positions at the time of President Nixon's announcement through the BOJ's yendenominated lending to banks to finance discounting foreign-currency denominated export bills. For the details of this scheme, see Bank of Japan (1986, pp.328-330). 
cent between August $16^{\text {th }}$, the day following Nixon's decision to close the gold window, and August $27^{\text {th }} \cdot{ }^{60}$ After August $27^{\text {th }}$, the BOJ stopped purchasing dollars at the old price of 360 yen. The yen was allowed to appreciate, although the BOJ still intervened to slow its movement, accumulating more reserves. Once the yen reached 308 to the dollar, a 16.9 per cent bilateral appreciation, it was re-pegged.

Expectations were that revaluation would have deflationary effects on the economy, leading companies to postpone investment and run down their inventories. In addition, it was argued that abandoning the dollar parity that had been the anchor for policy since the late 1940 s had negative effects on confidence. ${ }^{61}$

In response, the BOJ cut its discount rate by 50 basis points in December 1971 and by another 50 basis points in June 1972. A supplementary budget was passed for April 1971-March 1972, and a more expansionary stance was adopted for fiscal year 1972 with expenditure on general account up by 22 per cent and expenditure on public investment and lending through the FILP up by 32 per cent over the previous year.

The short-run impact of revaluation was relatively mild, reflecting the effects of all this monetary and fiscal stimulus. While exports fell by 0.1 per cent in the first quarter of 1972 (on a seasonally adjusted basis), they recovered strongly. In the fourth quarter of 1972, exports rose by 15.7 per cent from the same quarter of the previous year (in nominal yen-denominated terms). Exports of capital goods, such as general machinery, electrical machinery and transport equipment, rose by 28 per cent. ${ }^{62}$ The economy bottomed out in December 1971 according to the business cycle dates of the

\footnotetext{
${ }^{60}$ This refers to the combined reserves of the Bank of Japan and the Ministry of Finance.

${ }^{61}$ In the Bank of Japan's retrospective analysis, the Japanese economy, which had begun to recover from the post-1969 recession in the summer of 1971, started to weaken again from the second half of August due to the effects of the so-called "Nixon shock." Bank of Japan (1986), pp.357-358.
} 
Economic Planning Agency. Real GNP grew by more than 10 per cent on an annualized basis in the first quarter of 1972, and the inflation rate bottomed on a CPI basis in September 1972, with a 4.7 per cent year-on-year increase. ${ }^{63}$ As early as March of that year there was discussion of whether the revaluation had been sufficient to prevent the current account from remaining in strong surplus, large amounts of foreign reserves from being accumulated, and inflationary pressures from intensifying.

With benefit of hindsight, Komiya and Suda (1983b) argue that Japan waited too long to exit from the peg and to move to a managed float. They write that "the government should have revalued the central rate of the Smithsonian Agreement or moved to floating at least by the autumn of 1972. [But] at that time the government and Bank of Japan considered the avoidance of revaluation as the primary policy goal and conducted macroeconomic policies accordingly. However, these policies accentuated imbalances among the major countries, especially between Japan and the United States. Furthermore, they generated the great inflation from 1973 to $1974 \ldots$.. If the second shift to floating (in 1973) had been carried out half a year earlier and a tight monetary policy had been adopted, the outcome of policies could have shown a significant difference." ${ }^{\prime 64}$ When the Smithsonian Agreement collapsed in early 1973, the yen was again allowed to float upward, this time to 265 , at which point the BOJ again intervened to limit its fluctuation. ${ }^{65}$ Consistent with the advice tendered to China today, Japan's float

\footnotetext{
${ }^{62}$ The figure for transport equipment here does not include vehicles for personal use.

${ }^{63}$ Subsequently it accelerated to 11.3 per cent in 1973 and 22.6 per cent in 1974, reflecting a combination of strong domestic demand, excess liquidity and the rise in oil and other commodity prices.

${ }^{64}$ Komiya and Suda (1983b), pp.24, 31-2 (authors' translation).

${ }^{65}$ Komiya and Suda (1983b), p.41. It is interesting to note the parallels with Goldstein and Lardy's (2003) proposal for China for a two-step exit from the yuan peg, the first step being a one-time revaluation against the dollar and the second step, after a period, being the transition to a managed float.
} 
was heavily managed: the exchange rate was limited to a narrow range between 264 and 266 yen to the dollar through September 1973.

\section{Capital Controls and the Forward Market}

Throughout this period, exchange and capital controls remained in place. Restrictions on convertibility for purposes of transactions on current account were maintained into the $1960 \mathrm{~s} .{ }^{66}$ Each foreign currency transaction relating to imports required a license from MITI, while all foreign currency transactions for other purposes, such as transactions related to inward FDI, required one from the Ministry of Finance. Transactions on capital account were essentially suppressed. Up through 1963, the current account balance and changes in foreign reserves moved in lockstep, reflecting these pervasive controls on capital account.

The first step in liberalization was the establishment of yen accounts for nonresidents in 1960. The authorities then eliminated restrictions on transactions on current account in April 1964, accepting Article VIII of the Articles of Agreement of the International Monetary Fund. Inward investment was liberalized in 1968, but even then it was not entirely freed: significant restrictions on inward FDI remained into the 1970s.

The 1949 Foreign Exchange and Foreign Trade Control Law, which remained in effect until 1980, prohibited Japanese citizens from holding foreign exchange except with the permission of the authorities. There were also restrictions on the ability of Japanese financial institutions to maintain open positions in foreign exchange and on the ability of foreign financial institutions to take positions in domestically-issued yen-denominated

\footnotetext{
${ }^{66}$ See Fukao (1990) for details.
} 
securities. ${ }^{67}$ From 1968, restrictions on open positions were supplemented and then largely superceded by swap limits (yen conversion quotas under which the authorities set a ceiling for the net short spot positions of foreign currencies plus the amount of outstanding free yen liabilities to non-residents). ${ }^{68}$ This had the effect of limiting covered interest arbitrage by the banks, causing the forward rate to move more freely and making speculation more costly. ${ }^{69}$

Some of these restrictions were then tightened in the 1970s when the yen was unpegged, with the goal of limiting capital inflows. In 1972 controls were tightened on advances against exports, additional reserve requirements were imposed on increases in nonresident yen deposits, and limits were placed on nonresident purchases of Japanese securities. $^{70}$ Then in 1973, when Japan's current account swung into deficit first with the strong expansion of the economy and then the OPEC shock, controls on capital inflows were abolished while those on outflows were reinforced. When the yen strengthened in 1977, controls on the foreign currency deposits of residents were abolished, measures prohibiting residents from acquiring short-term foreign securities were eliminated, and a 50 per cent reserve requirement on increases in the yen deposits of nonresidents was instituted. $^{71}$ Indicative of the extent of these capital controls, covered interest parity (the interest differential between the U.S. and Japan adjusted for the difference between spot and forward exchange rates) holds closely after December 1980, the moment of deregulation, but not before. ${ }^{72}$

\footnotetext{
67 The allowance of open positions for authorized banks was reduced twice in the mid-1960s to inhibit short-term capital outflows. Ministry of Finance (1992), pp.192-3.

68 Ministry of Finance (1992), p.212 and Fukao (1990), pp.119-121.

${ }^{69}$ These ceilings were then transformed into limits on open positions in 1977 and abolished in 1984.

${ }^{70}$ Fukao (1990), p.24.

${ }^{71}$ Those reserve requirements were then doubled in 1978.

${ }^{72}$ See Ito (1986).
} 
For much of this period, authorization to participate in the foreign exchange market and the extent of permissible positions were subject to control by the Foreign Exchange and Foreign Trade Control Law and decrees. Only banks with approval from the government, so-called "authorized foreign exchange banks," were allowed to book transactions on both the spot and forward markets. As mentioned before, the open positions of authorized banks were capped by decree. ${ }^{73}$ These regulations influenced forward market activities. So-called speculative transactions were prohibited, and only exporters and importers were said to have the opportunity of speculating and then only within the volume of their trade. ${ }^{74}$

The development of the forward foreign exchange market depended on the relaxation of foreign exchange controls and also on the incentive to invest in forward cover. ${ }^{75}$ The collapse of the Bretton Woods system therefore triggered the expansion of

\footnotetext{
${ }^{73}$ In addition, residents were allowed to carry out foreign exchange transactions only when they were involved in trade and other limited transactions requiring foreign exchange. The law heavily regulated outward and inward portfolio investments. This restriction was called the "actual demand rule."

${ }^{74}$ Kawamura and Shibuichi (1961) explain this speculation as follows (p.11, authors' translation):
}

\begin{abstract}
"Apart from transactions based on actual demand (demand accompanied by actual trading such as exports and imports), speculative transactions can be carried out in the foreign exchange market. Forward transactions are sometimes used for purposes of speculation.... However, there is no room in Japan for speculation as described above because forward exchange contracts are allowed only on the basis of actual demand according to the Foreign Exchange Control Law. Transactions accompanied by actual demand can be used for speculation in certain cases. For example, exporters can expand their positions of forward foreign exchange well in advance when foreign currencies are expected to fall in the near future."
\end{abstract}

Komiya and Suda (1983a) point out that exports and imports were mainly settled in U.S. dollars and exporters and importers had the chance to speculate by controlling the amount of their open positions (pp.147-152). Of course, there were ambiguities in the application of these measures that still left some scope for currency speculation. But precisely the same point can be made about China today, where exchange controls are comprehensive but still far from watertight.

${ }^{75}$ Komiya and Suda (1983b) point out that trading volume of forward transactions increased as the spot market developed even under the fixed exchange rate system (p.23). It should be noted that even under the fixed exchange rate system, inter-bank and customer exchange rates were allowed to fluctuate within narrow bands after the deregulation of 1959 , encouraging transactions in the forward market to a certain extent. Prior to September 1959, the so-called MOF exchange rate, by which authorized foreign exchange banks traded with the MOF, and customer exchange rates were fixed by decree of the Finance Minister. Deregulation allowed these rates to fluctuate between 0.5 per cent above parity, 360 yen per dollar, and 0.5 per cent below it (the band later expanded to 0.75 per cent in 1963). At the same time, regulation of the 
foreign exchange transactions on both the spot and forward markets (Figure 5). This occurred only after the short-run disruption had passed, since the forward market stopped functioning with the yen's floating in August 1971. Initially, the banks stopped quoting forward exchange rates for their customers, and trading volume on the inter-bank market collapsed. Exchange controls were then tightened in reaction to the collapse of the Bretton Woods System, resulting in a lack of opportunities for arbitrage and a drying up of the forward market. Forward market transactions resumed only in late October. ${ }^{76}$

In sum, Japan experienced gradual liberalization of its international financial transactions in the three decades ending around 1980. But even then there were extensive restrictions on the ability of households and financial institutions to engage in crossborder financial transactions and interest arbitrage. Exchange controls had been partially relaxed prior to floating of the yen, but they were still far from eliminated. And various controls were tightened or reimposed following the shift to managed floating. ${ }^{77}$

Some skeptics of the feasibility of a more flexible renminbi exchange rate argue that full currency convertibility, including on capital account, is a necessary prerequisite for greater exchange rate flexibility in practice. Others suggest that floating requires a deep and liquid forward market, and that China should not permit the renminbi to vary more freely and be determined by market conditions until there is significant additional progress in developing the inter-bank forward market in Shanghai. ${ }^{78}$ Japanese

\footnotetext{
forward exchange rate against the dollar was abandoned. (Forward rates against other currencies had been already deregulated.) Ministry of Finance (1992), pp.42-4.

${ }^{76}$ Komiya and Suda (1983b), pp.22-23.

${ }^{77}$ Revealingly, Fukao (1990) entitles a section of his paper "From 1973 to 1980: A Managed Float with Controls on Capital Movements."

${ }^{78}$ At the time of writing, several banks, including the Big Four banks, have started forward exchange transactions with their customers on a "pilot basis" (People's Bank of China 2004b, p.56), but this is still far from a deep and liquid forward market. Among other things, the bank lack investment specialists with experience in managing foreign exchange exposures. Other foreign-exchange-market-related initiatives,
} 
experience in the 1970s does not suggest that it is necessary to complete the task of liberalizing the capital account and developing the inter-bank forward market before moving to a significantly more flexible exchange rate. It suggests that banks and firms in China now, like those in Japan after 1973, should be able to tolerate a further increase in exchange rate volatility so long as the central bank continues to intervene to avoid very sudden movements in the currency's level and sharp spikes in volatility.

\section{Effects of Exiting the Peg}

Efforts to identify the impact on Japan of exiting the peg are complicated by other disturbances hitting the economy around this time. By the early 1970s the high-growth period following World War II was coming to an end; after two decades of rapid exportand investment-led growth, much of the productivity gap vis-à-vis the United States had been closed. While the average annual rate of GDP growth decelerated from 12.1 per cent in 1960-69 to 7.5 per cent in 1970-73 and 3.8 per cent in 1973-85, it would be a mistake to attribute the entire shift to the change in exchange rate regime, since with the end of catch-up there would have been some slowdown in any case. In addition, the world economy grew very rapidly for two years following the exit, which may have cushioned the Japanese economy from any disruptive effects.

such as the enhancement of the Foreign Exchange Trade Centre, are largely limited to spot transactions. On 18 May 2005, inter-bank foreign currency trade was "formally introduced" in China. Previously, there was no trading platform for transactions between foreign currencies. The recent reform enables domestic financial institutions to trade eight pairs of foreign currencies in China; euro against U.S. dollar, Australian dollar against U.S. dollar, pound sterling against U.S. dollar, U.S. dollar against Swiss francs, U.S. dollar against Hong Kong dollar, U.S. dollar against Canadian dollar, U.S. dollar against Japanese yen and euro against Japanese yen. For the details of this reform, see People's Bank of China (2005). While there also exists a market in nondeliverable forwards in Hong Kong, this is not accessible, by design, to domestic entities seeking to hedge foreign exposures. 
As emphasized earlier, the motors of Japanese growth were exports and investment. One way of isolating the impact of the change in the exchange rate on growth is therefore to examine its effect on these two variables. Figure 6 juxtaposes capital investment in the manufacturing sector (as a share of GDP) with the real effective exchange rate. Investment shoots up once the real exchange rate comes down in the wake of the Korean War; it then declines in the early 1970s coincident with the appreciation of the real rate. The movement of manufacturing profits (current profits of the manufacturing sector as a share of GDP), upward after the early 1950s and then down after 1971, is consistent with the operation of this mechanism, with causality running from international competitiveness to manufacturing profitability and from there to capital formation in the manufacturing sector.

The problem is that other things were happening at the same time, some of which could have been affecting the real exchange rate, profitability and investment, with no causality running between them. The technological progress and industrial rationalization in the 1950s emphasized by Fujino (1988) and Kosai (1989) would have affected Japanese economic growth precisely by stimulating profitability and investment in manufacturing. The rapid growth of the world economy in 1971-3 could have supported investment and profitability in the face of a negative exchange-rate shock.

A more careful analysis of the connections between the exchange rate and investment is therefore required. A previous study along these lines is Miyagawa and Tokui (1994), who regress gross investment in manufacturing as a share of the capital stock on the real exchange rate and a vector of controls (a proxy for global demand, the ratio of wages to the cost of capital, and the ratio of intermediate input prices relative to 
the cost of capital). ${ }^{79}$ They confirm that appreciation (depreciation) of the real effective exchange rates had a negative (positive) impact on Japanese investment in the 1980s. ${ }^{80}$ This is in line with the findings of other studies where real appreciation reduces export prices relative to costs, squeezing profitability and discouraging investment.

Here we extend their analysis back to the 1950s and consider not just the bilateral rate against the dollar but the real effective exchange rate. We estimate an equation of the form:

$$
\mathrm{i}_{\mathrm{t}} / \mathrm{k}_{\mathrm{t}-1}=\alpha+\beta \operatorname{reer}_{\mathrm{t}-1}+\gamma \mathrm{w}_{\mathrm{t}-1} / \mathrm{c}_{\mathrm{t}-1}+\delta \mathrm{d}_{\mathrm{t}-1} / \mathrm{k}_{\mathrm{t}-1}
$$

where

i: real capital investment in manufacturing

$\mathrm{k}$ : real capital stock in manufacturing

reer: real effective exchange rate

w: real wage in manufacturing

c: user cost of capital

$\mathrm{d}$ : world income

We lag the independent variables, assuming time to build. Consistent with a Cobb-Douglas production function, we enter the wage and cost of capital in ratio form. $\mathrm{d}$, the GDP of major industrial countries, is our proxy for global demand for Japanese manufacturing products. It is normalized by the capital stock following the specification

\footnotetext{
${ }^{79}$ Miyagawa and Tokui (1994) use effective exchange rates provided by J.P. Morgan in their estimates. ${ }^{80}$ Other results are that global demand has a positive effect on investment, increases in the ratio of intermediate input prices to capital costs has a negative effect (as if capital and intermediate inputs are complements in production), and increases in the ratio of wages to capital costs has a positive effect (as if labor and capital are substitutes). Miyagawa and Tokui (1994) assume that trade industries are in a
} 
in Miyagawa and Tokui (1994). All variables are on annual basis and the sample period is $1955-1973 .^{81}$

A problem with estimating this relationship in levels is that many macroeconomic time series exhibit unit roots. The augmented Dickey-Fuller test confirms that the real exchange rate and the factor price ratio have unit roots. In contrast, the hypothesis of a unit root can be rejected at the one per cent level for the investment ratio and world income normalized by the capital stock. ${ }^{82}$ Estimating this relationship in first differences consequently may introduce a problem of overdifferencing. We therefore estimated the equation both in levels and differences.

Table 4 shows the results. When the relationship is estimated in levels, the real effective exchange rate enters significantly, with a positive coefficient, indicating that appreciation had a negative impact on manufacturing investment. ${ }^{83}$ The real wage relative to the user cost of capital is significant with a positive sign, indicating that a change in relative factor prices induces capital/labor substitution, other things equal. ${ }^{84}$ World income is also significant with a positive sign, confirming that an increase in world income had the expected positive effect on investment. The results using the differenced data, in the second panel, are consistent with these findings.

The effect of exchange rate on exports during high growth period is one of the major issues in the studies described in Section 3. Here, we estimate export function like that specified by Nakamura (1993):

condition of monopolistic competition where appreciation of their national currency leads to worsening the competitiveness and thus results in decline in share of national industries in the global market.

${ }^{81}$ Each variable is transformed into index whose level of 1955 is 100 . All data series are then expressed as logarithms.

${ }^{82}$ The results of the DF-GLS test, which is supposed to have enhanced power in small samples, show the same results.

${ }^{83}$ Note that real effective exchange rate here is defined as yen per unit of foreign currencies. 


$$
\operatorname{ex}_{\mathrm{t}}=\alpha+\beta \text { reer }_{\mathrm{t}}+\gamma \mathrm{d}_{\mathrm{t}}
$$

where

ex: real exports

reer: real effective exchange rate

d: world income

and $\alpha, \beta$ and $\gamma$ are parameters to be estimated.

The results, again estimated over the period 1955-73 with annual data series, are in Table $5 .^{85}$ Here estimates using the differenced data are more reliable given that we fail to reject the null hypothesis of a unit root in all series. ${ }^{86}$ The real effective exchange rate is significantly positive, confirming that the appreciation of the real exchange rate would have negatively affected Japanese exports. Global income is significant with positive sign, consistent with previous studies.

Simulating the impact of the exit on investment and exports requires an estimate of by how much the real exchange rate changed given post-1970 changes in the nominal exchange rate. Since regressing the real exchange rate on the nominal exchange rate would be tantamount to putting the nominal rate on both sides of the equation, we instead estimate a passthrough equation, regressing the WPI on the nominal effective exchange rate, foreign WPIs, and relevant controls. Since the real exchange rate is the ratio of domestic prices relative to foreign prices adjusted for the nominal exchange rate, we can use the results to estimate the impact of nominal appreciation on the real exchange rate (and hence on real variables like investment and export volumes).

\footnotetext{
${ }^{84}$ As in Miyagawa and Tokui (1994).

${ }^{85}$ All series are again transformed into logs prior to estimation.

${ }^{86}$ Using both the augmented DF and DF-GLS tests.
} 
The long-run relationship estimated here is of the form:

$$
w p i_{t}^{J P}=\beta_{0} e_{t}+\beta_{1} w p i_{t}^{F o r}+\Omega X+\varepsilon_{t}
$$

where $w p i^{J P}$ and $w p i^{F o r}$ are the logs of the Japanese and weighted average of foreign wholesale price indices, $e$ is the log of the nominal effective exchange rate (yen per unit of foreign currency) and $X$ is a vector of controls (quarterly dummies, a linear time trend, real GDP, and the natural logarithm of the oil price, which figured importantly in Japanese price trends in the 1970s and 1980s). Note that this is only one of many forms in which this relationship is estimated; others have, for example, put the exchange rate on the left and domestic prices on the right and attempted to use it to track exchange rate fluctuations. Since in this period the exchange rate was tightly managed, while domestic wholesale prices were free to move, it makes more sense to treat the exchange rate as exogenous and domestic prices are endogenous. ${ }^{87}$

The equation is estimated using quarterly data for 1957-1990. The passthrough coefficient in Table 6 is in the range of 0.1-0.2. These estimates are relatively low: using data for a later period, Campa and Goldberg (2002) obtain a long-run passthrough coefficient for Japan of 0.8 . But it is important to note that they consider import prices rather than wholesale prices, and wholesale prices are likely to move less, insofar as they include a large component of domestic prices which are less affected by exchange rate changes. Passthrough coefficients for other large economies such as the United States using relative wholesale prices also generate estimates on the order of 0.2 .

\footnotetext{
${ }^{87}$ And, of course, it is reasonable to assume that Japan was too small for its own inflation to significantly affect inflation in the rest-of-the-world aggregate.
} 
A potential problem for the results in Table 6 is that we cannot reject the hypothesis of a unit root in the dependent and independent variables (see Table 7). However, these results will be consistent if the individual series are cointegrated. We therefore tested for the presence of unit roots in the residuals. The tests in Table 8 indicate that the null hypothesis of a unit root can be rejected.

The next step is estimating a short-run relationship that will allow for a more accurate characterization of the dynamics of adjustment. We use the residual from the preceding regression, denoted $u_{t}$, as the error correction term in an equation designed to capture short-term dynamics.

$$
\Delta w p i_{t}^{J P}=\sum_{i=1}^{3} \gamma_{t-1}^{0} \Delta w p i_{t-1}^{J P}+\sum_{i=0}^{3} \gamma_{t-1}^{1} \Delta e_{t-1}+\sum_{i=0}^{3} \gamma_{t-1}^{2} \Delta w p i_{t-1}^{F o r}+\rho \hat{\mu}_{t-1}+\Omega^{\prime} \Delta X+\zeta_{t}
$$

We can solve this equation for the long-run effect of nominal appreciation on domestic prices (long-run passthrough), obtaining:

$$
\phi=\frac{\sum_{i=0}^{3} \gamma_{t-1}^{1}}{1-\sum_{i=1}^{3} \gamma_{t-1}^{0}}
$$

The estimates of this equation are in Table 9. The point is estimate of long-run passthrough is even smaller than before. However, this estimate is noisy due to the inclusion of some $\gamma^{0}$ and $\gamma^{1}$ coefficients that are not statistically distinguishable from zero. To correct for this we recalculated $\phi$ excluding $\gamma$ coefficients that were not statistically significant at the 10 per cent level. The passthrough coefficient derived in this manner, 
denoted $\phi$, is also reported in Table 9. These results are more stable across

specifications. They suggest a long-run passthrough coefficient of 0.25 .

A possible concern is that these results may be excessively influenced by the pre1971 period when the yen was pegged to the dollar. Since the change in the nominal exchange rate was zero in this period as far as the bilateral rate against the dollar is concerned, passthrough from the exchange rate to prices will be zero as well, by construction. ${ }^{88}$ We took two approaches to addressing this problem. First, we restricted the sample to the period after the peg was abandoned. The coefficient on the nominal exchange rate turns out to be roughly the same as before, suggesting that the attenuation problem is not serious. ${ }^{89}$ Alternatively, we created a dummy variable for the period of floating and interacted it with the nominal exchange rate terms, adding this vector to the explanatory variables. This provides a direct test of the hypothesis that passthrough changed with the shift from pegging to floating. The long-run regression now becomes:

$$
w p i_{t}^{J P}=\beta_{0} e_{t}+\theta_{0} e_{t}^{*} D^{P E G}+\beta_{1} w p i_{t}^{F o r}+\Omega X+\widetilde{\varepsilon}_{t}
$$

where exchange rate passthrough is now given by $\phi "=\beta_{0}+\theta_{0}$. The results confirm that passthrough was significantly higher in the floating period. ${ }^{90}$ But the additional effect is small; it has no noticeable impact on the overall level of long-run passthrough as estimated above.

\footnotetext{
${ }^{88}$ Note that nominal effective exchange rates in the pre-1971 period fluctuated to some extent (for details, see Section 3 and Figure 1).

${ }^{89}$ Arguments stemming from the Lucas Critique suggest that we might expect to find a higher passthrough coefficient in this later period insofar as floating made agents more aware of the possibility of exchange rate fluctuations. In practice this does not appear to be the case.

${ }^{90}$ When a constant term is also included in the equation.
} 
Recall that the nominal effective rate appreciated by 11.0 per cent between 1971Q2 and 1971Q4. Assuming a passthrough coefficient of 1/4, the induced appreciation of the real rate was three quarters of this, or 8.3 per cent. This is close to the actual appreciation of the real effective rate between 1971 and 1972 (see Figure 2). ${ }^{91}$ Between 1971Q1 and 1973Q1 the nominal effective rate rose by 26.2 per cent. Three quarters of this is 19.7 per cent. Again, this is rather close to the actual real appreciation observed in this period. We therefore take a real appreciation of 8.3 per cent as the short run impact and 19.7 per cent as the longer run impact of the exit.

We now are in a position to calculate the impact of the change in the nominal effective exchange rate on exports and investment. Taking the coefficients estimated on first-differenced data in Table 4 and 5, the short-run (1971-72) fall in exports is 8.6 per cent. The longer-run (1971-73) fall is 20.4 per cent. The impact on investment is larger: its level declines by 11.1 per cent between $1971-72$ as a result of the 8.3 per cent real appreciation. The long-run effect is four times as large. These are substantial effects.

These results for exports and investment are consistent with one another. Figure 7 suggests that Japanese firms responded to the short-run change in the exchange rate by cutting their margins: they did not raise prices commensurately, which meant that they absorbed the much of the impact. ${ }^{92}$ That export prices do not rise as quickly as consumer

\footnotetext{
${ }^{91}$ The actual appreciation on an annual average basis was 9.5 per cent.

${ }^{92}$ In 1971-2, Japanese wholesale export prices declined by 3.2 per cent, while wholesale prices rose by 1.6 per cent, consistent with this distinction - and with the idea that Japanese exporters absorbed the exchange rate shock by cutting margins and thereby maintaining export market share. This response clearly varied by sector. The Economic White Paper of 1972 discusses the effects of yen's revaluation on the competitiveness of exporters and price setting behavior of export sectors as follows (Economic Planning Agency 1972, pp.70-71, authors' translation).
}

"Looking at changes in export prices (on a foreign currency denominated basis) and export volumes in the period from the shift to a floating exchange rate system (in August 1971) to March in this year (1972), export volumes of electric machinery and transport equipment increased even though 
and wholesale prices in 1971-2 is consistent with this fact. In turn the decline in margins had a sharp negative impact on investment, which contributed to the recession that started in 1973.

Readers may wonder why a sharp slowdown in Japanese exports, investment and growth was not evident in 1972-3. Actual capital investment rose by almost 2 per cent between 1971 and 1973, while export volumes rose by 12 per cent. Our results suggest that the growth of exports and investment was mainly attributable to the rapid growth of world income, which rose by a cumulative 12 per cent in these two years. Normalized by the Japanese capital stock as we measure it, world demand increased by 34 per cent. $^{93}$ Fortuitous conditions like these cannot be taken for granted. They caution that allowing a large and sudden appreciation following the exit from the peg could have a substantial negative impact on demand and economic growth.

\section{Conclusion}

Our analysis of Japanese currency experience in the 1970s suggests that a rapidlygrowing, export-oriented economy can operate a floating exchange rate in the presence of capital controls and despite the absence of deep and liquid foreign currency forward

(foreign currency denominated) prices were raised enough to offset the impact of revaluation, reflecting strong competitiveness. The export volumes of steel and textiles fell due to the increase in export prices (on a foreign currency denominated basis) designed to partially absorb the effects of revaluation ... Some industries with weak competitiveness in the global market such as chemicals and foods were forced to keep export prices (on a foreign currency denominated basis) to maintain export volume.

${ }^{93}$ In the case of investment, other independent variables also moved in supportive directions. The ratio of wages to the cost of capital increased sharply, with both the numerator and denominator moving in supportive directions. Real wages increased by 22 per cent, while user cost of capital declined by 76 per cent due to the decline in the real interest rate. Real interest rates declined sharply: although the WPI increased by 15 per cent, the nominal bank lending rate rose only one per cent point. In this sense, monetary policy supported investment. In addition, public investment rose sharply in this period, suggesting that fiscal policy further supported investment. 
markets so long as the central bank manages that float. Allowing the exchange rate to float enables the authorities to better tailor domestic money and credit conditions to local needs as the economy moves from a monetary and financial system that relies on administrative guidance to one in which interest rates guide the allocation of money and credit and in which the capital account of the balance of payments becomes increasingly open. But it is important for the country to manage its exchange rate with domestic conditions in mind and to avoid the kind of large real appreciation that would significantly compromise profits, damage investment, and jeopardize financial stability, especially in the absence of deep and liquid forward exchange markets on which foreign exposures could be hedged. If the floating rate is appropriately managed, however, it should not be necessary to wait on the further development of forward markets before allowing the currency to exhibit significantly greater flexibility.

For China this suggests starting with a modest band widening and limited increase in flexibility, similar to the policies in fact introduced in July 2005, and not acceding to foreign pressure for a large initial revaluation that might interrupt the growth of exports and depress investment. Other aspects of the comparison with Japan in the 1970s - the narrower profit margins of firms in the Chinese export sector, the more limited capacity of Chinese banks to cope with the financial consequences of a change in currency values, and the larger share of exports in Chinese GDP (which means that a smaller revaluation is needed to eliminate a current account surplus of any absolute size) - similarly point to the advisability of the Chinese authorities' decision to start with a relatively small change in prevailing exchange rate. 
Both that history and our assessment of current circumstances suggest that the kind of large real appreciation that might result from a premature shift to free floating should be avoided in the next step. This kind of large appreciation is advocated in some circles as helping to solve the problem of "global imbalances" - as China's contribution to reducing the U.S. current account deficit. If Japan's experience in the 1970s is any guide, a large real appreciation runs the risk of damaging profitability and investment and thus of slowing growth. A Chinese "contribution" to solving the problem of global imbalances that has this effect is in no one's interest. 
Table 1. Annual Growth Rates of National Income

\begin{tabular}{ccc}
\hline & Japan (GNP) & China (GDP) \\
\hline $1913-50$ & 2.0 & \\
$1913-40$ & 4.0 & \\
$1955-71$ & 9.3 & 4.9 \\
$1950-78$ & & 9.4 \\
$1979-2003$ & & \\
$1960 \mathrm{~s}$ & 10.1 & \\
$1970 \mathrm{~s}$ & 4.7 & 9.7 \\
$1980 \mathrm{~s}$ & 4.0 & 10.4 \\
$1990 \mathrm{~s}$ & & 8.2 \\
$2000-03$ & & \\
\hline
\end{tabular}

Notes: Japanese figure from 1913 to 1950 is calculated by splicing at 1931 the two series for GNP provided by LTES. GNP in 1945 is assumed to be two-thirds of 1944, following Maddison (2001). Post-war figures are estimated by the Economic Planning Agency. China's data to 1978 are based on estimates by Maddison (2001), while those after 1979 are estimated by the IMF and the National Bureau of Statistics.

Sources:

Ohkawa, Kazushi, Nobukiyo Takamatsu and Yuzo Yamamoto (1974), Estimates of Long-Term Economic Statistics of Japan since 1868 volume 1, National Income, Toyo Keizai Shinposha.

Economic and Social Research Institute (ESRI), Cabinet Officie, Statistics Information Site (www.esri.cao.go.jp).

IMF, International Financial Statistics.

National Bureau of Statistics, People's Republic of China, China Monthly Economic Indicators. 
Table 2. Exports and the Current Account

\begin{tabular}{lrrrrrr}
\hline & \multicolumn{3}{c}{ Japan } & \multicolumn{3}{c}{ China } \\
\cline { 2 - 7 } & $\begin{array}{c}\text { Export } \\
\text { growth } \\
\text { (annual } \\
\text { average, \%) }\end{array}$ & $\begin{array}{c}\text { Share of total } \\
\text { US imports } \\
(\%)\end{array}$ & $\begin{array}{c}\text { Current } \\
\text { account } \\
\text { (billion } \\
\text { US\$) }\end{array}$ & $\begin{array}{c}\text { Export } \\
\text { growth } \\
\text { (annual } \\
\text { average, } \%)\end{array}$ & $\begin{array}{c}\text { Share of total } \\
\text { US imports } \\
(\%)\end{array}$ & $\begin{array}{c}\text { Current } \\
\text { account } \\
\text { (billion } \\
\text { US\$) }\end{array}$ \\
\hline $1950 \mathrm{~s}$ & 12.4 & 3.9 & 0.1 & & 0.2 & \\
$1960 \mathrm{~s}$ & 16.6 & 10.8 & 0.3 & & 0.0 & \\
$1970 \mathrm{~s}$ & 14.6 & 13.3 & 3.1 & 13.5 & 0.2 & -1.8 \\
$1980 \mathrm{~s}$ & 5.3 & 18.5 & 42.0 & 25.0 & 1.4 & 12.5 \\
$1990 \mathrm{~s}$ & 2.3 & 15.6 & 99.4 & 23.4 & 6.4 & 24.4 \\
\hline $2000 \mathrm{~s}$ & 3.5 & 10.7 & 114.0 & 22.4 & 10.4 & \\
\hline
\end{tabular}

Notes: Export growth is based on national currency-denominated figures. Share of US imports is calculated using US dollar-denominated figures. Share of US imports since 2000 is calculated using data for 2000-03. China's current account figure for the 1980s is the average for 1982-89. That since 2000 is the average for 2000-02. Japan's current account for the 2000s includes data through 2004.

Sources:

IMF, Balance of Payments Statistics.

IMF, Direction of Trade Statistics.

IMF, International Financial Statistics.

Bank of Japan, Balance of Payments Monthly.

National Bureau of Statistics of China, China Statistical Yearbook 2001.

Yamazawa, Ippei, and Yuzo Yamamoto (1978), Estimates of Long-Term Economic

Statistics of Japan since 1868, volume 14, Foreign Trade and Balance of Payments, Toyo Keizai Shinposha. 
Table 3. Savings and Investment Rates

\begin{tabular}{lcccc}
\hline & \multicolumn{2}{c}{ Japan } & \multicolumn{2}{c}{ China } \\
\cline { 2 - 5 } & Savings rate & Investment rate & Savings rate & Investment rate \\
\hline 1950 & 29.9 & 16.2 & & \\
1960 & 34.1 & 30.2 & & \\
1970 & 40.5 & 35.1 & 34.0 & 32.1 \\
1982 & & & 38.0 & 35.2 \\
1990 & & & 38.7 & 36.2 \\
2000 & 27.5 & 20.1 & & \\
$1^{\text {st }}$ half of 1950s & 29.0 & 24.4 & & \\
$2^{\text {nd }}$ half of 1950s & 35.8 & 32.4 & & \\
$1^{\text {st }}$ half of 1960s & 37.0 & 32.4 & 34.5 & 33.2 \\
$2^{\text {nd }}$ half of 1960s & & & 35.9 & 38.5 \\
$1^{\text {st }}$ half of 1980s & & & 39.9 & 38.5 \\
$2^{\text {nd }}$ half of 1980s & & & 40.7 & \\
$1^{\text {st }}$ half of 1990s & & & & \\
$2^{\text {nd }}$ half of $1990 \mathrm{~s}$ & & & & \\
\hline
\end{tabular}

Notes: Japan's rates are relative to GNP, China's relative to GDP. China's savings are the sum of gross capital formation and net current account. Figures for $1^{\text {st }}$ half of the $1980 \mathrm{~s}$ cover 1982-84.

Sources:

Ohkawa, Kazushi, Nobukiyo Takamatsu and Yuzo Yamamoto (1974), Estimates of Long-Term Economic Statistics of Japan since 1868 volume 1, National Income, Toyo Keizai Shinposha (Tables 1A, 6A).

National Bureau of Statistics of China, China Statistical Yearbook 2001 (Tables 3-11). IMF, International Financial Statistics. 


\section{Table 4. Determinants of Investment}

Annual Data

Estimated equation : $\mathrm{i}_{\mathrm{t}} / \mathrm{k}_{\mathrm{t}-1}=\alpha+\beta$ reer $_{\mathrm{t}-1}+\gamma \mathrm{w}_{\mathrm{t}-1} / \mathrm{c}_{\mathrm{t}-1}+\delta \mathrm{d}_{\mathrm{t}-1} / \mathrm{k}_{\mathrm{t}-1}$

Figures in parentheses are t-statistics.

\section{Levels}

\begin{tabular}{cccccc}
\hline Constant term & $\begin{array}{c}\text { Real effective } \\
\text { exchange rate }\end{array}$ & $\begin{array}{c}\text { Real wage / } \\
\text { User cost of } \\
\text { capital }\end{array}$ & World Income & Adjusted R & DW statistic \\
\hline-28.63 & 6.13 & 0.61 & 0.62 & 0.21 & 1.14 \\
$(-2.20)^{*}$ & $(2.46)^{*}$ & $(1.99)^{*}$ & $(2.35)^{*}$ & & \\
\hline
\end{tabular}

\section{Differences}

\begin{tabular}{cccccc}
\hline Constant term & $\begin{array}{c}\text { Real effective } \\
\text { exchange rate }\end{array}$ & $\begin{array}{c}\text { Real wage / } \\
\text { User cost of } \\
\text { capital }\end{array}$ & World Income & Adjusted R & DW statistic \\
\hline 0.05 & 3.14 & 0.86 & 1.22 & 0.50 & 1.32 \\
$(0.60)$ & $(1.88)^{*}$ & $(2.50)^{*}$ & $(2.04)^{*}$ & & \\
\hline
\end{tabular}

Notes: 1.User cost of capital is calculated as:

$$
\mathrm{r}=\mathrm{P}_{\mathrm{c}} *(\mathrm{i}-\pi+\mathrm{d}) / \mathrm{P}_{\mathrm{w}}
$$

$r \quad$ : user cost of capital

$\mathrm{P}_{c}$ : price index of capital goods (1952-1960), or that of investment goods (1960-1971)

$\mathrm{P}_{\mathrm{w}}$ : wholesale price index (WPI)

i : banks' lending rate (the averaged interest rate of banks' new loans in December in each year)

$\pi$ : percentage change in WPI

d : depreciation rate

2. ** denotes 1 per cent significance; $*$ denotes 5 per cent significance.

3. For details on the construction of the real effective exchange rate, see data appendix.

4. Capital investment in the first quarter of 1955 is assumed as the same as averaged amount of second to fourth quarter. Capital stock at the end of 1952 is assumed as the same level as that of the end of March in 1953.

5. Real wage is total cash earnings per regular employee in manufacturing sector deflated by WPI.

6. World income is aggregated real GDP of eleven countries (see data appendix).

7. World income is normalized by the capital stock, following Miyagawa and Tokui (1994).

Source: see data appendix. 


\section{Table 5. Determinants of Exports \\ Annual Data}

Estimated equation : $\mathrm{ex}_{\mathrm{t}}=\alpha+\beta$ reer $_{\mathrm{t}}+\gamma \mathrm{d}_{\mathrm{t}}$

Figures in parentheses are t-statistics.

\section{Levels}

\begin{tabular}{ccccc}
\hline Constant term & $\begin{array}{c}\text { Real effective } \\
\text { exchange rate }\end{array}$ & World Income & Adjusted R & DW statistic \\
\hline-13.45 & 0.89 & 3.05 & 0.99 & 1.19 \\
$(-9.65)^{* *}$ & $(3.12)^{* *}$ & $(72.32)^{* *}$ & & \\
\hline
\end{tabular}

Differences

\begin{tabular}{ccccc}
\hline Constant term & $\begin{array}{c}\text { Real effective } \\
\text { exchange rate }\end{array}$ & World Income & Adjusted R & DW statistic \\
\hline 0.04 & 1.04 & 2.27 & 0.35 & 2.08 \\
$(0.85)$ & $(3.13)^{* *}$ & $(2.23)^{*}$ & & \\
\hline
\end{tabular}

Notes: $1 . * *$ denotes 1 per cent significance; *denotes 5 per cent significance.

2. Real exports are deflated by export price index on Long-Term Economic Statistics (LTES) basis (1953-1959) or by that of WPI basis (1960-1971).

3. For details regarding the construction of the real effective exchange rate, see data appendix.

4. World income is aggregated real GDP of eleven countries (see data appendix).

Source: See data appendix. 
Table 6. Long Term Passthrough

Quarterly Data

\begin{tabular}{ccccc}
\hline & $(1)$ & $(2)$ & $(3)$ & $(4)$ \\
\hline Nominal Effective & 0.142 & 0.142 & 0.136 & 0.137 \\
Exchange Rate (ln) & $(0.030)^{* * *}$ & $(0.030)^{* * *}$ & $(0.028)^{* * *}$ & $(0.029)^{* * *}$ \\
Weighted Foreign & 0.354 & 0.354 & 0.555 & 0.555 \\
Price Level (ln) & $(0.048)^{* * *}$ & $(0.048)^{* * *}$ & $(0.064)^{* * *}$ & $(0.064)^{* * *}$ \\
Oil Price (ln) & 0.114 & 0.114 & 0.061 & 0.061 \\
& $(0.013)^{* * *}$ & $(0.014)^{* * *}$ & $(0.017)^{* * *}$ & $(0.017)^{* * *}$ \\
GDP (ln) & 0.067 & 0.067 & 0.160 & 0.161 \\
& $(0.006)^{* * *}$ & $(0.006)^{* * *}$ & $(0.022)^{* * *}$ & $(0.022)^{* * *}$ \\
\hline Quarterly Dummies & No & Yes & No & Yes \\
Trend & No & No & Yes & Yes \\
Observations & 136 & 136 & 136 & 136 \\
$\mathrm{R}^{2}$ & 0.99 & 0.99 & 0.99 & 0.99 \\
\hline
\end{tabular}

Standard errors in parenthesis.

*significant at $10 \%$; ** significant at $5 \%$; *** significant at $1 \%$. 
Table 7. Unit Root Tests

Generalized Dickey-Fuller Test

All variables in logs

\begin{tabular}{llcl}
\hline \multicolumn{1}{c}{ Variable } & & No Trend & Trend \\
\hline \multirow{2}{*}{ WPI Japan } & Level & 0.108 & -15.40 \\
Nominal Effective & First Difference & $-3.744 * * *$ & $-4.211^{* * *}$ \\
Exchange Rate & First Difference & 0.972 & 0.568 \\
Weighted Foreign & Level & $-5.332^{* * *}$ & $-5.209 * * *$ \\
Price Level & First Difference & 0.578 & -1.621 \\
Oil Price & Level & $-2.616^{* * *}$ & $-2.980 * * *$ \\
& First Difference & 0.312 & -1.482 \\
GDP & Level & $-5.002 * * *$ & $-4.900^{* * *}$ \\
& First Difference & 0.090 & -0.522 \\
\hline
\end{tabular}

All tests include a constant and four lags.

$*, * *, * * *$ indicates unit root hypothesis can be rejected at $10 \%, 5 \%$ and $1 \%$ significance levels respectively.

Table 8. Unit Root Tests

Generalized Dickey-Fuller Test

\begin{tabular}{lcc}
\hline \hline & No Trend & Trend \\
\hline Equation 1 & -1.653 & $-3.086^{* *}$ \\
Equation 2 & -1.706 & $-3.115^{* *}$ \\
Equation 3 & -1.692 & $-2.875^{*}$ \\
Equation 4 & -1.741 & $-2.899^{*}$ \\
\hline \hline
\end{tabular}

All tests include a constant and one lag. $*, * *, * * *$ indicates unit root hypothesis can be rejected at $10 \%, 5 \%$ and $1 \%$ significance levels respectively. 
Table 9. Passthrough Dynamics

\begin{tabular}{|c|c|c|c|c|}
\hline & (1) & (2) & (3) & (4) \\
\hline \multirow{2}{*}{$\Delta p_{t-1}$} & 0.633 & 0.651 & 0.631 & 0.649 \\
\hline & $(0.092)^{* * *}$ & $(0.093)^{* * *}$ & $(0.095)^{* * *}$ & $(0.096)^{* * * *}$ \\
\hline \multirow{2}{*}{$\Delta p_{t-2}$} & -0.101 & -0.119 & -0.122 & -0.140 \\
\hline & (0.108) & $(0.111)$ & $(0.112)$ & $(0.114)$ \\
\hline \multirow[t]{2}{*}{$\Delta p_{t-3}$} & 0.025 & 0.036 & 0.013 & 0.023 \\
\hline & $(0.095)$ & (0.096) & (0.098) & (0.099) \\
\hline \multirow[t]{2}{*}{$\Delta e_{t}$} & 0.091 & 0.089 & 0.087 & 0.085 \\
\hline & $(0.027)^{* * *}$ & $(0.027)^{* * *}$ & $(0.027)^{* * *}$ & $(0.028)^{* * *}$ \\
\hline \multirow{2}{*}{$\Delta e_{t-1}$} & -0.007 & -0.004 & -0.006 & -0.003 \\
\hline & $(0.031)$ & $(0.031)$ & $(0.032)$ & $(0.032)$ \\
\hline \multirow[t]{2}{*}{$\Delta e_{t-2}$} & -0.016 & -0.022 & -0.01 & -0.016 \\
\hline & $(0.031)$ & $(0.031)$ & $(0.031)$ & $(0.031)$ \\
\hline \multirow{2}{*}{$\Delta e_{t-3}$} & -0.038 & -0.033 & -0.031 & -0.026 \\
\hline & $(0.030)$ & $(0.030)$ & $(0.030)$ & $(0.031)$ \\
\hline \multirow[t]{2}{*}{$\Delta p^{*}{ }_{t}$} & 0.283 & 0.267 & 0.275 & 0.259 \\
\hline & $(0.098)^{* * *}$ & $(0.099)^{* * *}$ & $(0.100)^{* * *}$ & $(0.101)^{* * * *}$ \\
\hline \multirow[t]{2}{*}{$\Delta p_{t-1}^{*}$} & -0.058 & -0.032 & -0.089 & -0.063 \\
\hline & (0.109) & $(0.111)$ & $(0.113)$ & $(0.114)$ \\
\hline \multirow{2}{*}{$\Delta p_{t-2}^{*}$} & 0.219 & 0.200 & 0.203 & 0.184 \\
\hline & $(0.108)^{* *}$ & $(0.109)^{*}$ & $(0.111)^{*}$ & (0.112) \\
\hline \multirow[t]{2}{*}{$\Delta p_{t-3}^{*}$} & -0.101 & -0.098 & -0.125 & -0.121 \\
\hline & $(0.092)$ & $(0.093)$ & $(0.094)$ & $(0.096)$ \\
\hline \multirow{2}{*}{$\Delta o i l_{t}$} & 0.030 & 0.030 & 0.028 & 0.027 \\
\hline & $(0.009)^{* * *}$ & $(0.009)^{* * *}$ & $(0.009)^{* * *}$ & $(0.009)^{* * *}$ \\
\hline \multirow{2}{*}{$\Delta o i l_{t-1}$} & -0.021 & -0.021 & -0.014 & -0.015 \\
\hline & $(0.009)^{* *}$ & $(0.010)^{* *}$ & $(0.009)$ & (0.009) \\
\hline \multirow{2}{*}{$\Delta o i l_{t-2}$} & -0.015 & -0.013 & -0.011 & -0.009 \\
\hline & $(0.011)$ & $(0.011)$ & $(0.011)$ & $(0.011)$ \\
\hline \multirow[t]{2}{*}{$\Delta o i l_{t-3}$} & 0.000 & -0.001 & 0.005 & 0.004 \\
\hline & $(0.010)$ & $(0.010)$ & $(0.010)$ & $(0.010)$ \\
\hline \multirow[t]{2}{*}{$\Delta g d p_{t}$} & 0.003 & 0.001 & 0.023 & 0.021 \\
\hline & $(0.059)$ & $(0.059)$ & $(0.064)$ & $(0.065)$ \\
\hline \multirow[t]{2}{*}{$\Delta g d p_{t-1}$} & 0.090 & 0.094 & 0.107 & 0.11 \\
\hline & $(0.056)$ & $(0.057)$ & $(0.062)^{*}$ & $(0.062)^{*}$ \\
\hline \multirow[t]{2}{*}{$\Delta g d p_{t-2}$} & -0.000 & -0.008 & 0.006 & -0.002 \\
\hline & $(0.059)$ & $(0.059)$ & $(0.063)$ & (0.063) \\
\hline \multirow[t]{2}{*}{$\Delta g d p_{t-3}$} & 0.033 & 0.036 & 0.033 & 0.036 \\
\hline & $(0.054)$ & $(0.054)$ & $(0.058)$ & $(0.059)$ \\
\hline \multicolumn{5}{|l|}{$\wedge$} \\
\hline \multirow{2}{*}{$\mu_{t-1}$} & -0.153 & -0.154 & -0.13 & -0.130 \\
\hline & $(0.039)^{* * *}$ & $(0.039)^{* * *}$ & $(0.039)^{* * *}$ & $(0.039)^{* * *}$ \\
\hline \multirow[t]{2}{*}{$\bar{\varphi}$} & 0.069 & 0.068 & 0.085 & 0.084 \\
\hline & $(0.106)$ & $(0.109)$ & $(0.100)$ & $(0.103)$ \\
\hline$\varphi^{\prime}$ & 0.249 & 0.256 & 0.237 & 0.243 \\
\hline & $(0.102)^{* *}$ & $(0.109)^{* *}$ & $(0.101)^{* *}$ & $(0.108)^{* *}$ \\
\hline Quarterly Dummies & $\mathrm{NO}$ & YES & $\mathrm{NO}$ & YES \\
\hline Trend & NO & NO & YES & YES \\
\hline Observations & 132 & 132 & 132 & 132 \\
\hline $\mathrm{R}^{2}$ & 0.75 & 0.75 & 0.74 & 0.74 \\
\hline
\end{tabular}


Figure 1. Nominal Effective Exchange Rate (1949=100)

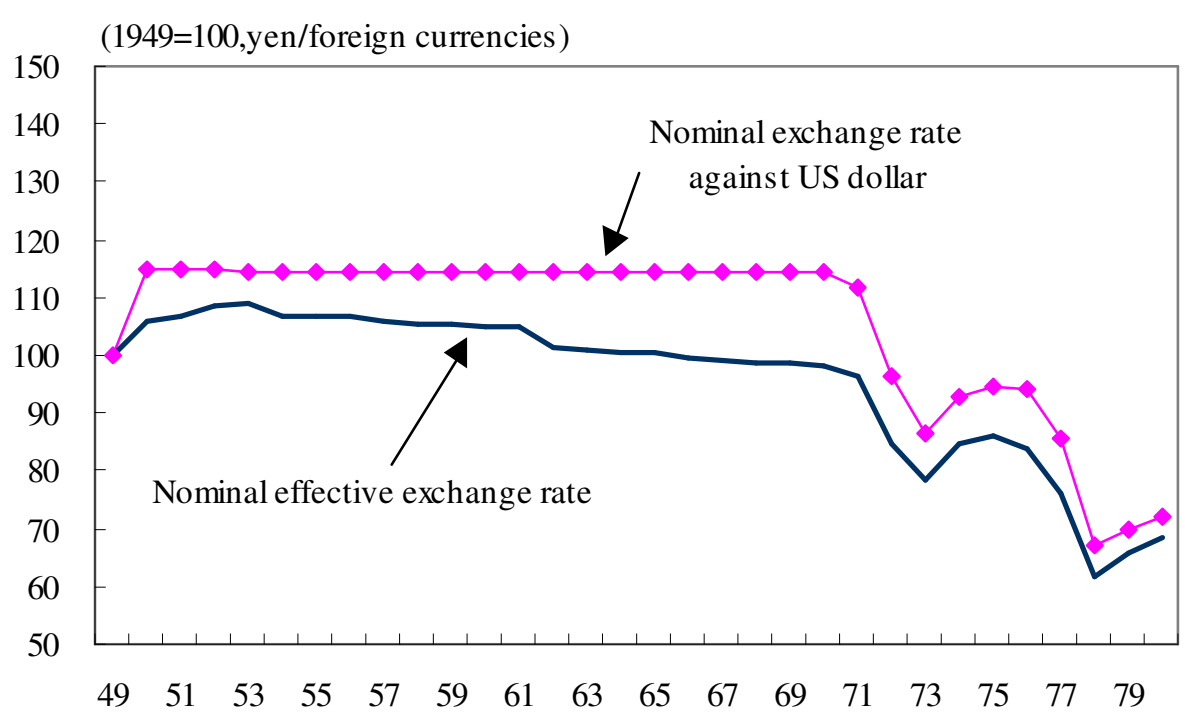

Sources: See data appendix.

Figure 2. Real Effective Exchange Rate (1949=100)

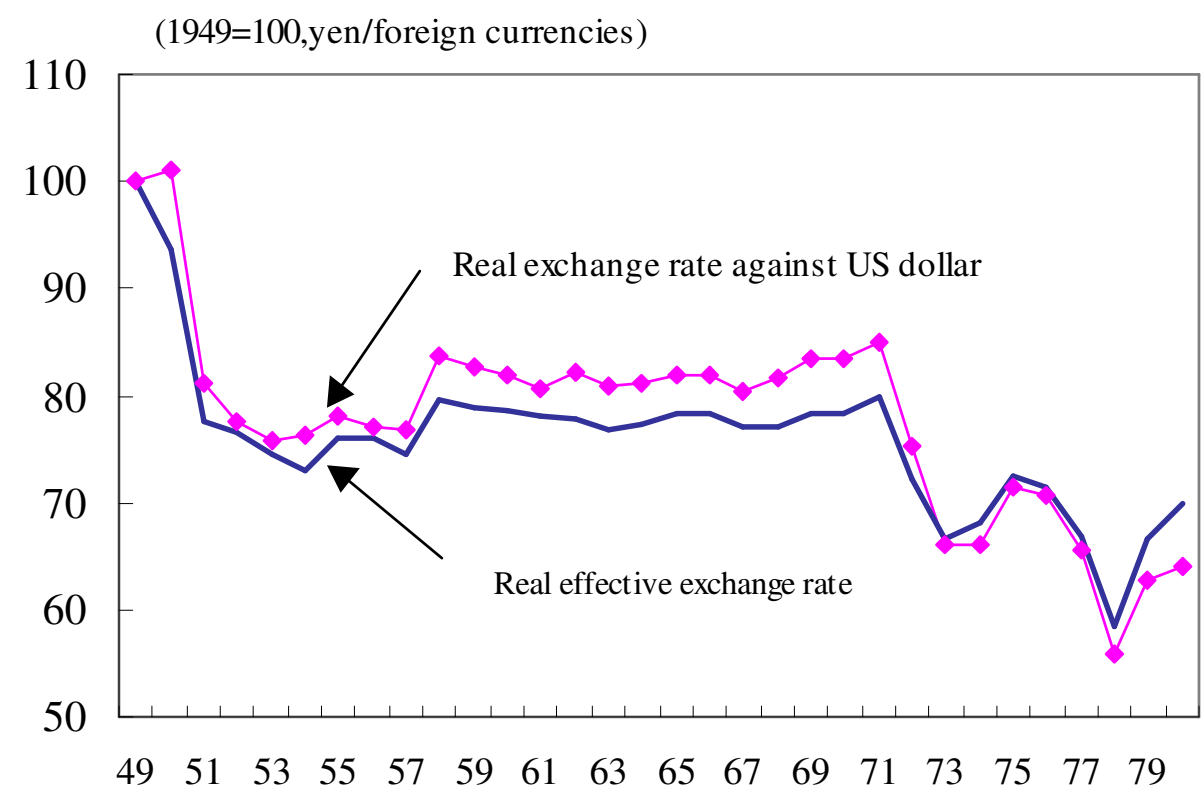

Sources: See data appendix. 
Figure 3. Prices $(1949=100)$

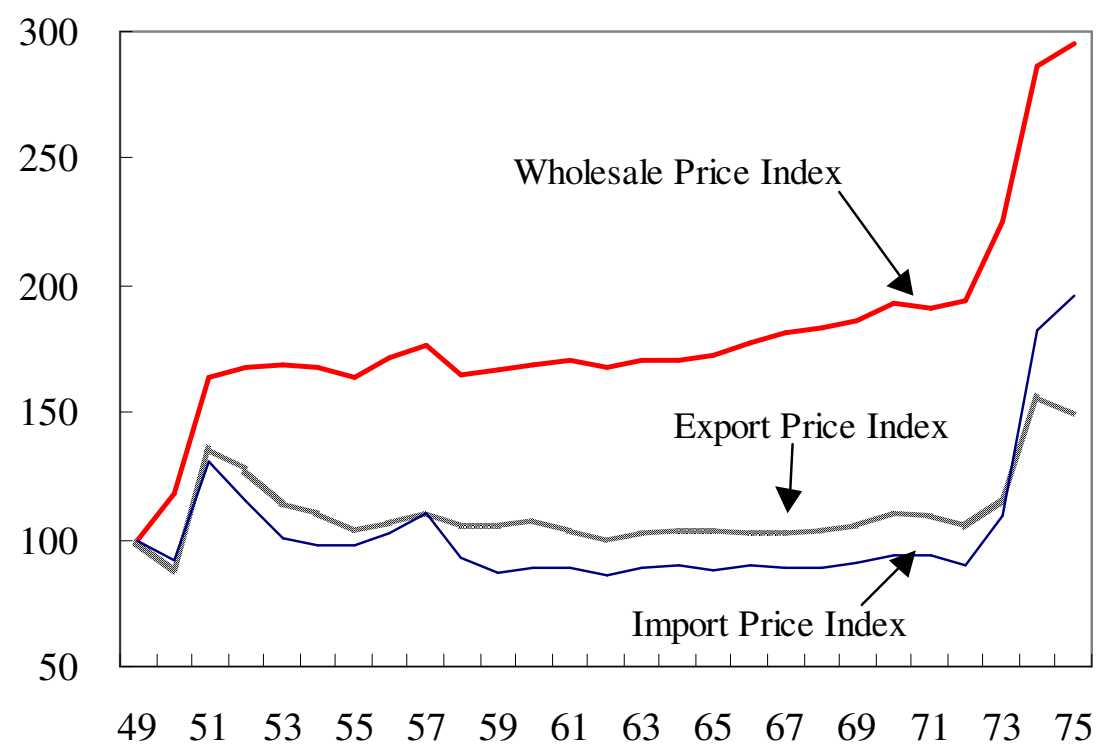

Sources: Bank of Japan, Wholesale Price Index,

Ohkawa, Kazushi, Tsutomu Noda, Nobukiyo Takamatsu, Saburo Yamada, Minoru Kumazaki, Yuichi Shionoya and Ryoshin Minami (1967), Estimates of Long-Term Economic Statistics of Japan since 1868 volume 8: Prices, Toyo Keizai Shinposha.

Figure 4. Unit Price of Exports $(1951=100)$

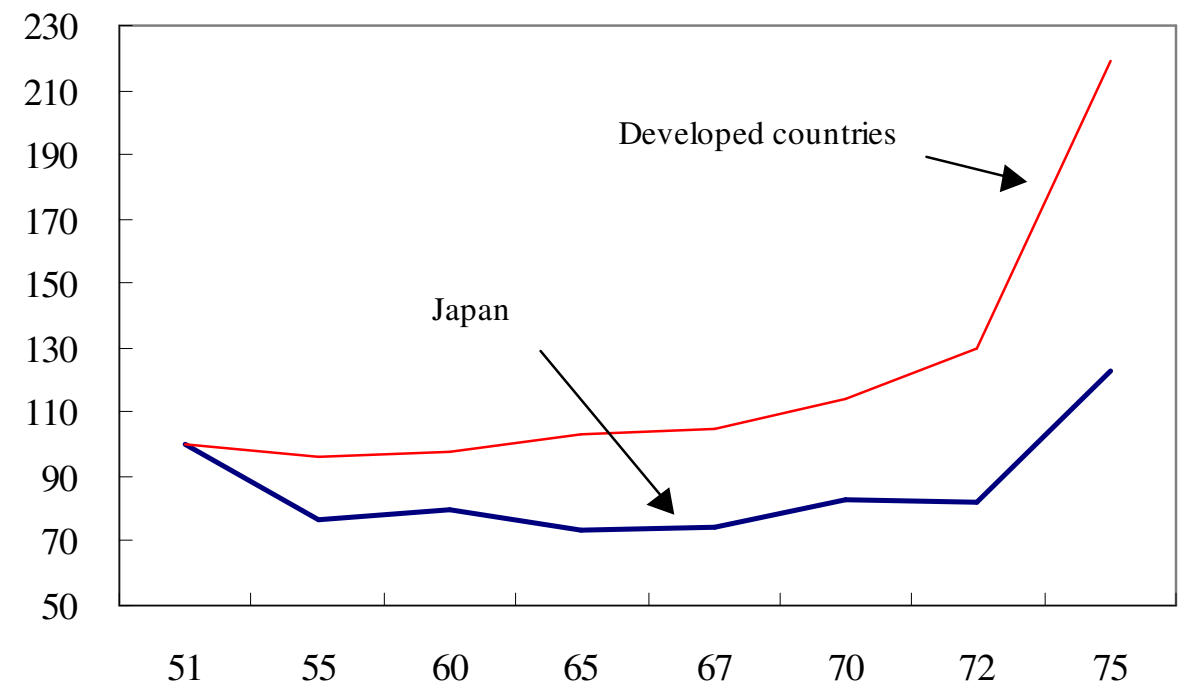

Source: Nakamura (1993), p.214, Table 61. 
Figure 5. Foreign Exchange Transaction Volume (1965-75)

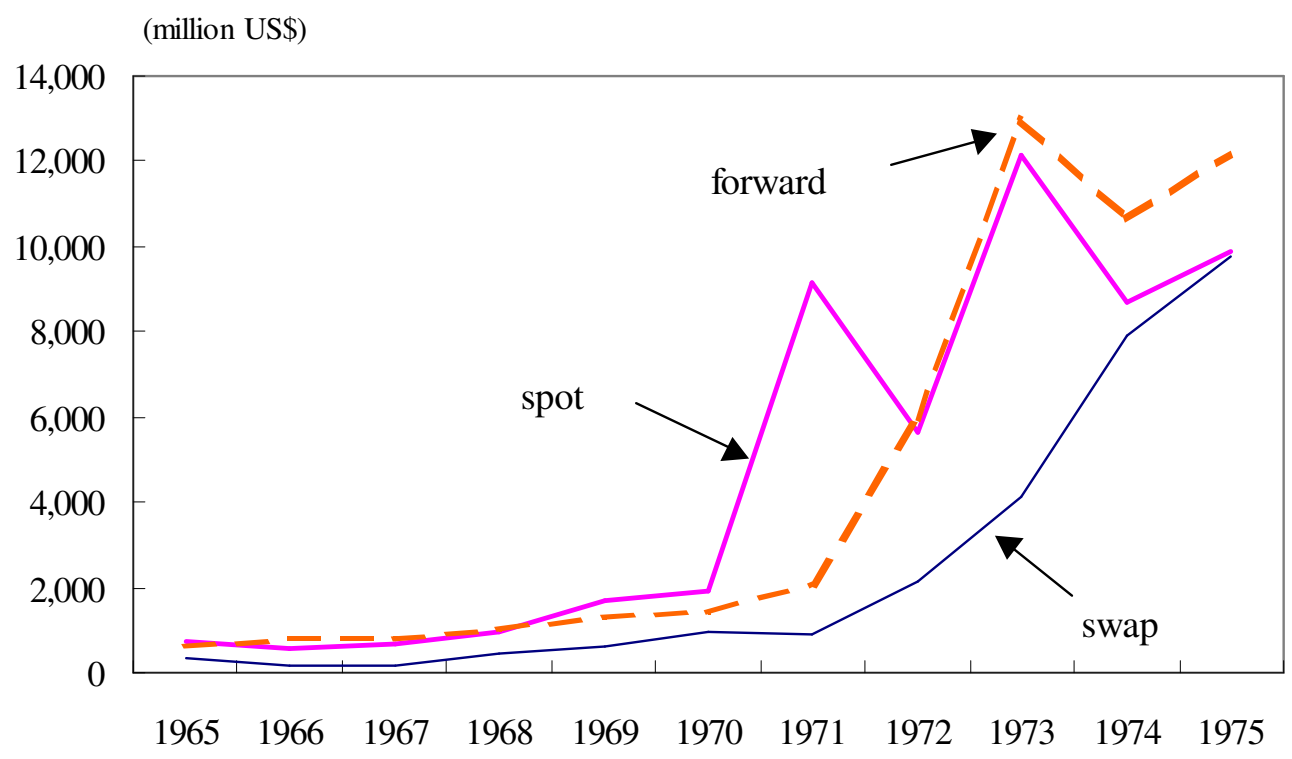

Note: Intraday trading volume, monthly averaged for December of each year.

Source: Nikkei Newspaper (Nihon Keizai Shinbun) 
Figure 6. Real Effective Exchange Rate (REER) and Investment (1949=100; \%)

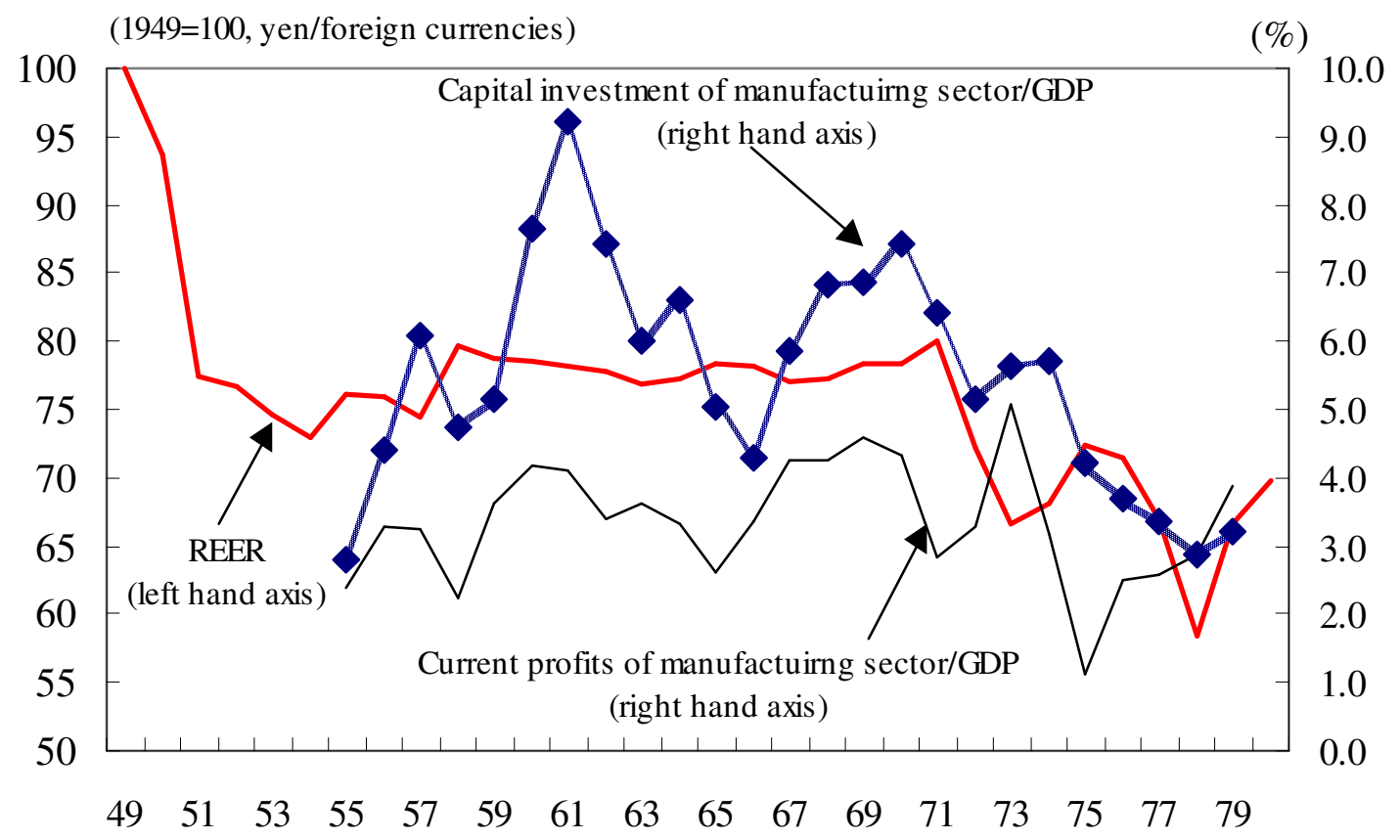

Sources: Ministry of Finance (1977), The Collected Data Series of Financial Statement Statistics of Corporations by Industry (Hojin Kigyo Tokei Kiho Syuran).

Economic and Social Research Institute (ESRI), Cabinet Officie, Statistics Information Site (www.esri.cao.go.jp).

For REER, see data appendix. 
Figure 7. Export Price Index/Input Price Index of Export Sectors

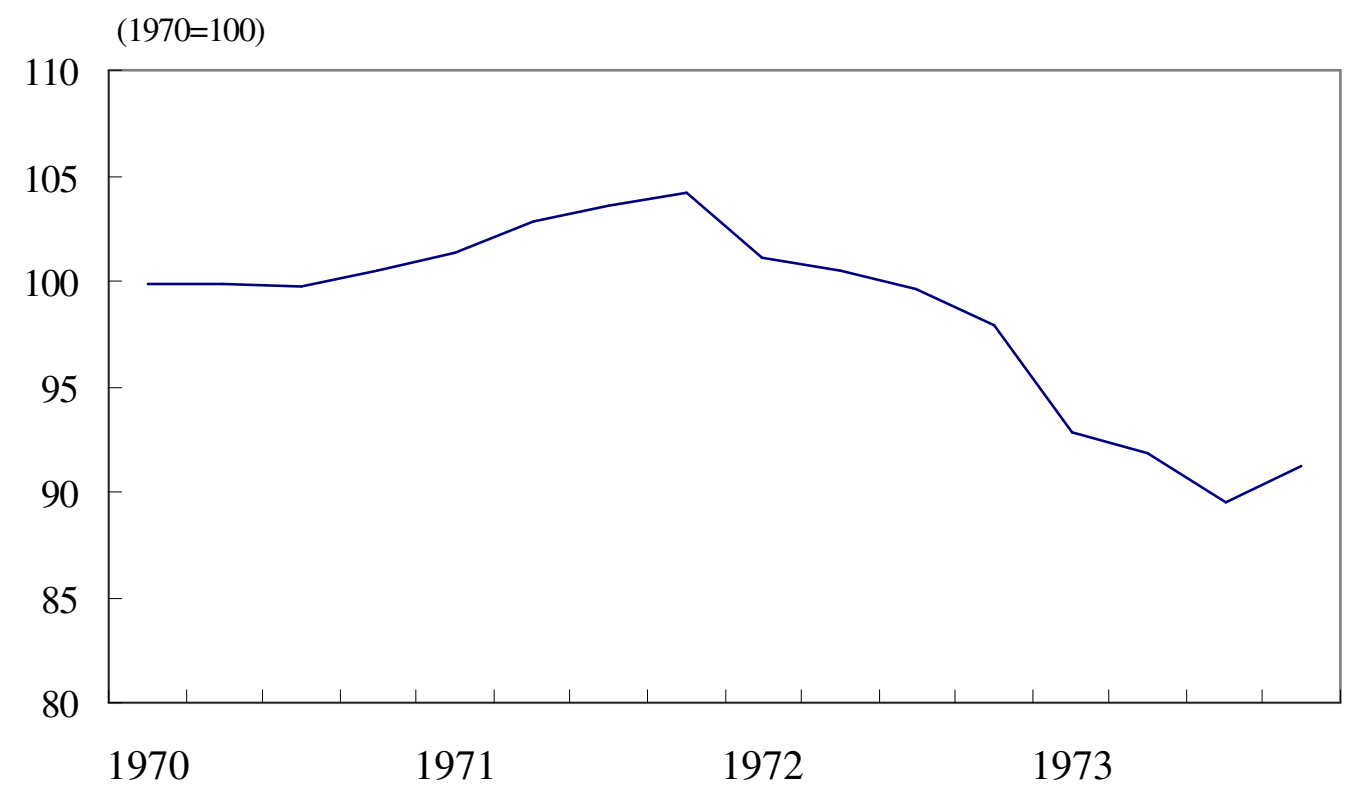

Sources: see data appendix. 


\section{Data Appendix}

a) Nominal effective exchange rates (NEER)

Nominal effective exchange rates consist of yen exchange rates against the currencies of 17 countries: the United States, the United Kingdom, West Germany, Greece, Italy, the Netherlands, Sweden, Switzerland, Canada, Venezuela, Australia, India, Iran, South Korea, Thailand, the Philippines and South Africa. These are the countries that meet the following criteria; imports from Japan in 1960 exceed 10 billion yen, and both price data and foreign exchange rate data series are available from 1949 to 1990. (South Korea is an exception as its wholesale price index is not available in 1950. As figures in 1949 and 1951 are identical, we assume that the WPI in 1950 was unchanged from 1949.) The 17 bilateral rates are weighted by the value of imports from Japan, updated every five years. Note that the series depicted in Figure 1 excludes nominal exchange rate against South Korea as its extreme increase (its level in 1970 is 300 times larger than that of 1949) dominated the trends of other currencies.

b) Real effective exchange rates (REER)

Real effective exchange rates consist of yen exchange rates against the currencies of the same 17 countries. Each nominal exchange rate is normalized by the wholesale or producer price indices of Japan and the country in question, and weighted as above. For Japan's wholesale price indices, domestic wholesale price index is used from 1960 while overall wholesale price index, which includes export and import prices, is used to 1959 due to data constraints. Note that the Figure 2 excludes the real exchange rate against South Korea for the same reason as above. Among the econometric results reported in the text, those which contain the data in the mid-1950s, namely investment and export equations, exclude South Korea from the weighted average to avoid the effects of the high-inflation episodes at the time.

c) World income (D)

We estimate world income by aggregating the GDPs of 11 countries: Australia, Belgium, Canada, France, Germany, Italy, Japan, Sweden, the Netherlands, the United States and United Kingdom with import value-based weights in 1955, 1960, 1965, 1970 and 1975. Imports of these countries account for about 60 per cent of world imports.

d) Sources for Table 4

Ministry of Finance, Financial Statements Statistics of Corporations (Hojin Kigyo Tokei), each issue; International Monetary Fund, International Financial Statistics, various issues; Direction of Trade Statistics, various issues; Maddison (2001); Mitchell (1998a, 1998b,1998c); Ministry of Trade and Industry, Annual Report of the Foreign Trade of Japan (Nihon Boueki Nenpyo), various issues; Bank of Japan (1986), One Hundred Year 
History of the Bank of Japan, Volume of collection of historical materials; Bank of Japan (1987), Hundred-Year Statistics of Wholesale Prices in Japan.

e) Sources for Table 5

International Monetary Fund, International Financial Statistics, various issues; Direction of Trade Statistics, various issues; Maddison (2001); Mitchell (1998a, 1998b); Ministry of Trade and Industry, Annual Report of the Foreign Trade of Japan (Nihon Boueki Nenpyo), various issues; Bank of Japan (1987), Hundred-Year Statistics of Wholesale Prices in Japan; Yamazawa, Ippei and YuzoYamamoto (1978), Estimates of Long-Term Economic Statistics of Japan since 1868. Vol.14: Foreign Trade and Balance of Payments.

\section{f) Sources for Figure 7}

Input prices for export sectors are calculated using input price indices for industries whose export dependence in 1974-5 was more than 20 per cent: precision instruments, transport equipment, steel, general machinery, and textiles. Input price indices for these sectors are aggregated using their weights in the 1970 input price index. The source is: Bank of Japan, Price Indexes Annual, various issues. 


\section{References}

Abegglen, James (1958), The Japanese Factory, Glencoe, Ill.: Free Press.

Ackley, Gardner and Hiromitsu Ishi (1976), "Fiscal, Monetary and Related Policies," in Hugh Patrick and Henry Rosovsky (eds), Asia's New Giant, Washington, D.C.: The Brookings Institution, pp.154-247.

Angel, Robert (1991), Explaining Economic Policy Failure: Japan in the 1969-1971 International Monetary Crisis, New York: Columbia University Press.

Association of Public and Corporate Bond Underwriters (Koshasai Hikiuke Kyokai) (1980), History of Public and Corporate Bond Market in Japan, Tokyo: Association of Public and Corporate Bond Underwriters (in Japanese, Nihon Koshasai Shijo Shi).

Bank of Japan (1976), The Financial System of Japan, Tokyo: Bank of Japan (in Japanese, Waga Kuni no Kinyu Seido)

Bank of Japan (1985), One Hundred Year History of the Bank of Japan, Volume 5, Tokyo: Bank of Japan (in Japanese, Nihon Ginko Hyakunenshi).

Bank of Japan (1986), One Hundred Year History of the Bank of Japan, Volume 6, Tokyo: Bank of Japan (in Japanese, Nihon Ginko Hyakunenshi).

Campa, Jose Manuel and Linda S. Goldberg (2002), "Exchange Rate Pass-Through into Import Prices: A Macro or Micro Phenomenon?” NBER Working Paper no. 8934 (May).

Dooley, Michael, David Folkerts-Landau and Peter Garber (2003), "An Essay on the Revived Bretton Woods System," NBER Working Paper no.9971 (September).

Economic Planning Agency (1972), Economic White Paper of 1972, Tokyo: Printing Bureau of Ministry of Finance (in Japanese, Showa 47 Nen-ban Keizai Hakusho).

Eichengreen, Barry (2004), “Chinese Currency Controversies," Asian Economic Papers (forthcoming).

Forum for Foreign Exchange Rate Policy (Kawase Seisaku Kenkyu-Kai) (1971), “A Recommendation for Adjustment of the Yen Rate by a Crawling Peg," Shukan Toyo Keizai (special issue), 30 August (in Japanese, "En Reto no Kokizami Chosei ni tsuite no Teigen").

Fujino, Shozaburo (1988), “The Balance of Payments of Postwar Japan, Part One: Overvaluation of Exchange Rate of 360 Yen," Keizai Kenkyu 39, pp.97-108 (in Japanese, "Sengo Nihon no Kokusai Shushi"). 
Fukao, Mitsuhiro (1990), “Liberalization of Japan's Foreign Exchange Controls and Structural Changes in the Balance of Payments," BOJ Monetary and Economic Studies 8, pp.1-65.

Goldstein, Morris and Nicholas Lardy (2003), "Two-Stage Currency Reform for China," The Asian Wall Street Journal (12 September).

Hayami, Masaru (1982), Ten Years' Experience with Floating: Voyage without a Chart, Tokyo: Toyo Keizai Shinpo Sha (in Japanese, Hendo Soba Sei 10 Nen: Kaizu naki Kokai).

Horiuchi, Akiyoshi (1984), "Economic Growth and Financial Allocation in Postwar Japan," Brookings Discussion Paper in Economics no. 18 (August).

Hoshino, Naoki (1958), “The Intention of Mr. Erhard,” Daiyamondo, 15 November, 1958 (in Japanese, Eaharuto no Shin’i).

Hutchison, Michael and Carl Walsh (1992), "Empirical Evidence on the Insulation Properties of Fixed and Flexible Exchange Rates: The Japanese Experience," Journal of International Economics 32, pp.241-264.

Ishii, Kanji (1991), Japanese Economic History, Tokyo: University of Tokyo Press, Second Edition, (in Japanese, Nihon Keizaishi).

Ito, Takatoshi (1986), "Capital Controls and Covered Interest Parity Between the Yen and the Dollar," Economic Studies Quarterly 37, pp.223-241.

Kawamura, Yozo and Tadashi Shibuichi (1961), The Practice of Forward Foreign Exchange, Tokyo: Gaikoku Kawase Boeki Kenkyu Kai (in Japanese, Sakimono Kawase no Jitsumu).

Kojima, Kiyoshi (eds) (1972), Structure and Development of Japanese Trade, Tokyo: Shiseido.

Komiya, Ryutaro (1988), Current Japanese Economy: Macroeconomic Perspectives and International Economic Relations, Tokyo: University of Tokyo Press (in Japanese, Gendai Nihon Keizai).

Komiya, Ryutaro and Miyako Suda (1983a), Contemporary International Finance: Theory, History and Policy; Theory Volume, Tokyo: Nihon Keizai Shinbun Sha (in Japanese, Gendai Kokusai Kinyuron, Riron-hen).

Komiya, Ryutaro and Miyako Suda (1983b), Contemporary International Finance: Theory, History and Policy, Volume for History and Policy, Tokyo: Nihon Keizai Shinbun Sha (in Japanese, Gendai Kokusai Kinyuron, Rekishi Seisaku-hen). 
Kosai, Yutaka (1989), "Economic Policy During the Era of High Growth," in Yasukichi Yasuba and Takenori Inoki (eds), Economic History of Japan, Volume 8: High Growth, Tokyo: Iwanami Shoten, pp.209-272, (in Japanese, "Kodo Seichoki no Keizai Seisaku," Nihon Keizaishi).

Krause, Lawrence and Sueo Sekiguchi (1976), "Japan and the World Economy," in Hugh Patrick and Henry Rosovsky (eds), Asia's New Giant, Washington, D.C.: The Brookings Institution, pp.385-457.

Kure, Bunji and Kinzo Shima (1987), Deregulation of Interest Rates: New Edition, Tokyo: Yuhikaku (in Japanese, Kinri Jiyuka: Shinpan).

Maddison, Angus (2001), The World Economy: A Millennial Perspective, Paris: OECD.

Mason, Mark (1982), American Multinationals and Japan, Cambridge, Mass.: Harvard University Press.

Mikuni, Akio and R. Taggart Murphy (2002), Japan's Policy Trap: Dollars, Deflation, and the Crisis of Japanese Finance, Washington, D.C.: The Brookings Institution.

Ministry of Finance (1976), The Financial History of Japan: The Allied Occupation Period, Volume 3, Tokyo: Ministry of Finance (in Japanese, Showa Zaisei Shi).

Ministry of Finance (1991a), History of Financial and Monetary Policies in Japan, 195273: Finance: Monetary Policy and Financial System, Part I, Volume 9, Tokyo: Ministry of Finance (in Japanese, Showa Zaisei Shi).

Ministry of Finance (1991b), History of Financial and Monetary Policies in Japan, 195273: Finance: Monetary Policy and Financial System, Part II, Volume 10, Tokyo:

Ministry of Finance (in Japanese, Showa Zaisei Shi).

Ministry of Finance (1992), History of Financial and Monetary Policies in Japan, 195273: International Finance and External Economic Affairs, Part II, Volume 12, Tokyo: Ministry of Finance (in Japanese, Showa Zaisei Shi).

Ministry of Trade and Industry (1990), History of Trade and Industrial Policies, Volume 6, Tokyo: Tsusho Sangyo Chosa Kai (in Japanese, Tsusho Sangyo Seisaku Shi).

Mitchell, Brian (1998a), The International Historical Statistics】 Americas 1750-1993, Basingstroke: Palgrave Macmillan.

Mitchell, Brian (1998b), The International Historical Statistics】 Europe 1750-1993, Basingstroke: Palgrave Macmillan. 
Mitchell, Brian (1998c), The International Historical Statistics $\square$ Africa, Asia \& Oceania 1750-1993, Basingstroke: Palgrave Macmillan.

Mitsubishi Heavy Industry Ltd. (1967), History of Mitsubishi Shipbuilding Ltd., Tokyo: Mitsubishi Heavy Industry Ltd. (in Japanese, Mitsubishi Zosen Kabushikikaisha Shashi).

Miwa, Ryoichi (2003), "Postwar Democratization and Economic Reconstruction" in Nakamura Takafusa and Konosuke Odaka (eds), Economic History of Japan, Volume 3: A Dual Structure, Oxford: Oxford University Press.

Miyagawa, Tsutomu and Joji Tokui (1994), Economics of Strong Yen, Tokyo: Toyo Keizai Shinpo Sha (in Japanese, Endaka no Keizaigaku).

Nakamura, Takafusa (1993), The Japanese Economy: Its Growth and Structure, Tokyo: University of Tokyo Press, Third edition (in Japanese, Nihon Keizai Shi: Sono Seicho to Kozo).

Nakamura, Takafusa (2003), “The Age of Turbulence: 1937-54," in Nakamura Takafusa and Konosuke Odaka (eds), Economic History of Japan, Volume 3: A Dual Structure, Oxford: Oxford University Press.

Odaka, Konosuke (1989), "The Trace of Growth (2)," in Yasukichi Yasuba and Takenori Inoki (eds), Economic History of Japan, Volume 8: High Growth, Tokyo: Iwanami Shoten (in Japanese, "Seicho no Kiseki(2)," Nihon Keizaishi).

Odaka, Konosuke (1999), “Japanese-Style’ Labour Relations,” in Tetsuji Okazaki and Masahiro Okuno-Fujiwara (eds), The Japanese Economic System and Its Historical Origins, Oxford: Oxford University Press.

Ohkawa, Kazushi and Henry Rosovsky (1973), Japanese Economic Growth, Stanford: Stanford University Press.

Okazaki, Tetsuji (1993), Japanese Industrialization and the Steel Industry: A Comparative Institutional Analysis of Economic Development, Tokyo: University of Tokyo Press (in Japanese, Nihon no Kogyoka to Tekko Sangyo: Keizai Hatten no Hikaku Seido Bunseki).

Okazaki, Tetsuji (1999), “Corporate Governance," in Tetsuji Okazaki and Masahiro Okuno-Fujiwara (eds), The Japanese Economic System and Its Historical Origins, Oxford: Oxford University Press.

Organization for Economic Growth and Cooperation (1994), Employment Outlook, Paris: OECD.

People's Bank of China (2004a), China Monetary Policy Report: Quarter One, 2004, Beijing: China Financial Publishing House. 
People's Bank of China (2004b), China Monetary Policy Report: Quarter Four, 2004, Beijing: China Financial Publishing House.

People's Bank of China (2005), "Foreign Currency Trading Formally Introduced to the Inter-bank Foreign Exchange Market," Press Release, www.pbc.gov.cn/english.

Shimada, Haruo, Toyoaki Hosokawa and Atsushi Seike (1982), "The Analysis of the Adjustments of Wage and Employment," Keizai Kenkyu, no.84 (in Japanese, Chingin oyobi Koyo Chosei Katei no Bunseki).

Shimomura, Osamu (1971), "Keeping the Parity Should Be the Principle of Economic Policy," Shukan Toyo Keizai (special issue), 30 August (in Japanese, Heika Iji koso Keizai Seisaku no Kihon dearu).

Shinohara, Miyohei (1959), "Liberalization and Exchange Rate of 360 Yen," Ekonomisuto, 10 November (in Japanese, "Jiyuka to 360 Yen Reto"), reprinted in Japan and the World Economy (1989), pp.22-30, Tokyo: Chikuma Shobo (in Japanese, Sekai Keizai to Nihon).

Suzuki, Yoshio (eds) (1987), The Japanese Financial System, Oxford: Clarendon Press. Tachi, Ryuichiro and Ryutaro Komiya (1960), Under-Liquidity and Monetary Policy in Japan,” Economic Studies [Keizai Kenkyu], vol.11, no.3, pp.288-295.

Takahashi, Kamekichi (1971), "Yen's Revaluation,” Asahi Newspaper, 4 May 1971 (in Japanese, En Kiriage).

Takamura, Naosuke (1971), The Introduction for the History of Japanese Cotton Spinning Industry, Tokyo: Hanawa Shobo, (in Japanese, Nihon Bosekigyo-shi Josetsu).

Toyota Motor Corporation (1987), Unlimited Creativity: Fifty Year History of Toyota Motor Corporation, Toyota: Toyota Motor Corporation (in Japanese, Sozo Kagiri Naku: Toyota Jidosha Goju-nen Shi).

Trezise, Philip and Yukio Suzuki (1976), "Politics, Government, and Economic Growth," in Hugh Patrick and Henry Rosovsky (eds), Asia's New Giant, Washington, D.C.: The Brookings Institution, pp.753-811.

Yasuba, Yasukichi and Takenori Inoki (1989), “An Overview: 1955-80," in Yasukichi Yasuba and Takenori Inoki (eds), Economic History of Japan, Volume 8: High Growth, Tokyo: Iwanami Shoten, pp.1-56 (in Japanese, "Gaisetsu, 1955-80 Nen," Nihon Keizaishi). 